\title{
ENERGY USE IN JAPAN AND THE UNITED STATES
}

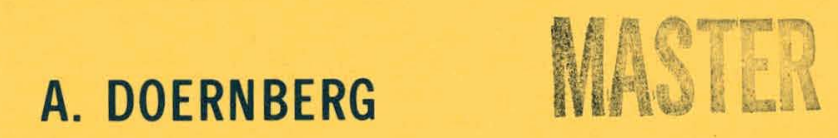

\section{AUGUST 1977}

\author{
Prepared for the \\ OFFICE OF THE ASSISTANT ADMINISTRATOR FOR PLANNING, ANALYSIS AND EVALUATION \\ UNITED STATES DEPARTMENT OF ENERGY \\ by the \\ TECHNOLOGY ASSESSMENT GROUP \\ NATIONAL CENTER FOR ANALYSIS OF ENERGY SYSTEMS
}

BROOKHAEN NATIONAL LABORATORY ASSOCIATED UNIVERSITIES, INC. UNDER CONTRACT NO. EY-76-C-02-0016 WITH THE

UNITED STATES DEPARTMENT OF ENERGY 


\section{DISCLAIMER}

This report was prepared as an account of work sponsored by an agency of the United States Government. Neither the United States Government nor any agency Thereof, nor any of their employees, makes any warranty, express or implied, or assumes any legal liability or responsibility for the accuracy, completeness, or usefulness of any information, apparatus, product, or process disclosed, or represents that its use would not infringe privately owned rights. Reference herein to any specific commercial product, process, or service by trade name, trademark, manufacturer, or otherwise does not necessarily constitute or imply its endorsement, recommendation, or favoring by the United States Government or any agency thereof. The views and opinions of authors expressed herein do not necessarily state or reflect those of the United States Government or any agency thereof. 


\section{DISCLAIMER}

Portions of this document may be illegible in electronic image products. Images are produced from the best available original document. 
BNL 50713

UC-95c

(Energy Conservation-Systems Modeling and Performance Assessment - TID-4500)

\title{
ENERGY USE IN JAPAN AND THE UNITED STATES
}

\author{
A. DOERNBERG
}

\section{AUGUST 1977}

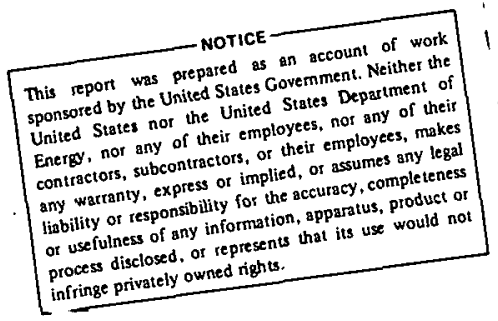

Prepared for the

OFFICE OF THE ASSISTANT ADMINISTRATOR FOR PLANNING, ANALYSIS AND EVALUATION UNITED STATES DEPARTMENT OF ENERGY

by the

TECHNOLOGY ASSESSMENT GROUP

NATIONAL CENTER FOR ANALYSIS OF ENERGY SYSTEMS

BROOKHAVEN NATIONAL LABORATORY

UPTON, NEW YORK: 11973 


\section{NOTIGE}

This report was prepared as an account of work sponsored by the Unitcd States Government. Neither the United States nor the United States Department of Energy (DOE), nor any of their employees, nor any of their contractors, subcontractors, or

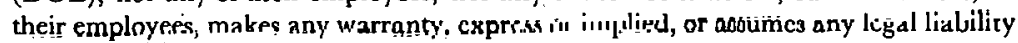
or responsibility for the accuracy, completeness or usefulness of any information, apparatus, product or process disclosed, or represents that its use would not infringe privately owned rights.

Printed in the United States of America Available trom

National Technical Information Service U.S. Department of Commerce 5285 Port Royal Road Springfield, VA 22161

Price: Printed Copy $\$ 5.25$; Microfiche $\$ 3.00$ 
TABLE OF CONTENTS

$\underline{\text { Page }}$

Acknowledgment . . . . . . . . . . . . . . . . vi

Abstract ...................... vii

Summary and Conclusions . . . . . . . . . . . . . viii

I. Introduction ....................... 1

Measure of Gross Domestic Product . . . . . . . . . . . 2

II. Energy Supply . . . . . . . . . . . . . . . . . 7

III. Energy Consumption by Sectors . . . . . . . . . . . . . 11

III-1 Electric Generation . . . . . . . . . . . . 13

III-2 Industrial Sector . . . . . . . . . . . . 15

III-2-1 Energy Use in Industry . . . . . . . . . . 17

GDP Originating in Industry . . . . . . . .

Eliergy per GDP Originating in Industry . . •

Energy Intensity of Industrial Mix . . . .

III-2-2 Comparison of Specific Energy Requirements . .

Iron and Steel . . . . . . . . . . . •

Aluminum .................

Cement ....................

Pulp and Paper .............. .

III-3 Transportation Sector . . . . . . . . . . 37

III-4 Residential Sector . . . . . . . . . . 4 42

III-5 Commercial Sector . . . . . . . . . . . 46

References ..................... 53 
Figure No.

$\underline{\text { Title }}$

Page No.

S-1 Japan Reference Energy System 1974 . . . . . . . .

$\mathrm{x}$

S-2 United State Reference Energy System 1974 . . . . . .

xi

S-3 Sectoral Energy Differentials, Japan-United States . . xiii

1 Inputs to Blast Furnaces, 1974 . . . . . . . . .

\section{LIST OF TABLES}

Table No.

$\underline{\text { Title }}$

Page No.

S-1 Prices and Taxes for Petroleum Products . . . . . . . xiv

1 Gross Domestic Product Per Capita . . ..........

2 Gross Domestic Product, Selected Industrailized Countries................... 5

3 Energy Supplies, 1974 . . . . . . . . . . . . 8

4 Energy Consumption by Sectors, 1974 . . . . . . .

5 Electric Generarton, 1974 . . . . . . . . . . .

. 6 Installed Electric Generating Capacity . . . . . . .

7 United States Energy Consumption in Industry, 1974 . .

8 Japan Energy Consumption in Industry, 1974 . . . . . .

9 Energy Consumption in Industry Per \$GDP Originating in Industry ..................... 23

10 Major Users of Energy in Industry . . . . . . . . .

11 Production of Industrial Groods, 1973 . . . . . . . .

12 Value of Shipments in Manufacturing 1971 . . . . . . 
Table No.

Title

Page No.

13 Japan Iron and Steel Industry, Coke and Oil Input Per Tonne of Raw Steel............. 30

14. Steelmaking by Process, Percent, 1974 . . . . . . . 31

15 Oxygen Requirements, Cu-Ft Per Ton of Raw Steel . . . . 33

16 Energy Input, Iron and Steel Industry ............ . 33

17 Energy Use Per Ton of Aluminum ... . . . . . . . . . 35

18. Energy Requirement Per Ton of Cement . . . . . . . . 36

19 Purchased Energy Per Ton of Paper . . . . . . . . . 38

20 Transportation Energy . . . . . . . . . . . . 40

21 Transportation Industries, 1974 . . . . . . . . . 41

22 Fuel Efficiencies . . . . . . . . . . . . 4 43

23 Fuels to Residential Sector, 1974 . . . . . . . . . 44

24 Residential Primary Energy Consumption . . . . . . . 45

25 Energy Use and Ownership of Appliances . . . . . . . 48

26 Energy Use, Commercial Sector, Japan 1972 . . . . . . 50

27 United States Commercial Energy Use, 1974 . . . . . . . 51 


\section{ACKNOWLEDGMENT}

Dr. Shigei Yasukawa, participant for Japan at the International Energy Agency's Systems Analysis Project, presently conducted at Brookhaven National Laboratory, has been invaluably helpful in providing data for this study. Ms. Yasuko Ysumi Sanborn has been enormously generous with her time translating from the Japanese in addition to her otherwise busy work load at the Center. 


\section{ABSTRACT}

A comparative study of energy consumption in Japan and the United States was undertaken in much the same spirit as a Sweden - United States comparison done earlier, i.e., a search for unique technological features that help explain at least in part the energy per capita differential between the two countries. In the case of Sweden there are technological differences (district heating, insulation); in the case of Japan for the most part there are not. Standard of living and to a lesser degree cultural differences impact largely on the residential and transportation sectors.

In the introduction, the ratios of energy per capita and energy per dollar of Gross Domestic Product (GDP) are presented. The exchange rates utilized to convert GDP to a common currency are discussed in detail. Brief sections on the energy supply and electric generation situation in Japan are included for background Information, followed by the body of the report devoted to the energy consumption sectors.

The industrial sector merits most of our attention because Japan's industrial capacity is second only to that of the United States among industrialized nations and it is here where an intercountry comparison can reveal possibilities of teshnningy transfer, First, a gross energy efficiency indicator for all industry (measured as industrial energy use per dollar of GDP originating in industry) is established. This is followed by detailed presentations of specific energy inputs (per ton of product) for four energy intensive industries: iron and steel, aluminium, cement, and pulp and paper.

Sections on the transportation, residential and commercial energy use reveal large differences in consumption largely due to what is labelled "standard of living" (housing size, automobile ownership, selection of transportation 
modes). In large part, however, the differencs in energy use have their roots in cultural idiosyncrasies. Technical features generally do not emerge in the comparison of these consumption sectors except for well recognized ones such as automobile fleet efficiency.

Finally, the section on conclusions underscores the usefulness of intercountry comparisons for industrial processes and delineates the limitations of such studies with respect to personal use of energy. Among the group of industrialized nations, Japan and the United States are probably the extreme case in illustrating these limitations. 
A comparative study of Japan - United States energy use was pursued in much the same spirit as a Sweden - United States comparison published earlier, i.e., a search for unique technological features that help explain at least part of the energy per capita differential between the two countries. In the case of Sweden these are present (district heating, insulation); in the case of Japan it appears they are not.

Statistically, the energy consumption differences between the United States and Japan are very large. Total per capita energy consumption in Japan is $37 \%$ of that of the United States. Gross Domestic Product (GDP) per capita in 1974 in Japan was $44 \%$ of the United States measured in 1970 prices and at the official exchange rate, and measured for the same year with a rate (called "purchasing power parity") that is based on domestic price levels the GDP per capita was $63 \%$ of the United States. The distinguished author and expert on Japan, Edwin 0. Reischauer asserts in his recent book* that statistics such as GDP bias comparisons in favor of Japan and do not reflect the overcrowding, cramped living quarters and threats of environmental disaster that are inimical to an enhancement of "standard of living."

The configurations of the 1974 energy systems for Japan and the United States are summarized in Figures $S-1$ and $S-2$ respectively, in which supply to demand energy flows are quantified in quadrillion British Thermal Units ( $10^{15}$ $\mathrm{Btu}=1.055 \times 10^{18}$ Joules). It clearly shows Japan's massive dependence on imported crude oil, and of imported coal for its iron and steel industry. The contribution of hydropower is comparatively higher than in the United States

\footnotetext{
*Edwin 0. Reischauer, The Japanese (Belknap/Harvard University Press, 1977).
} 


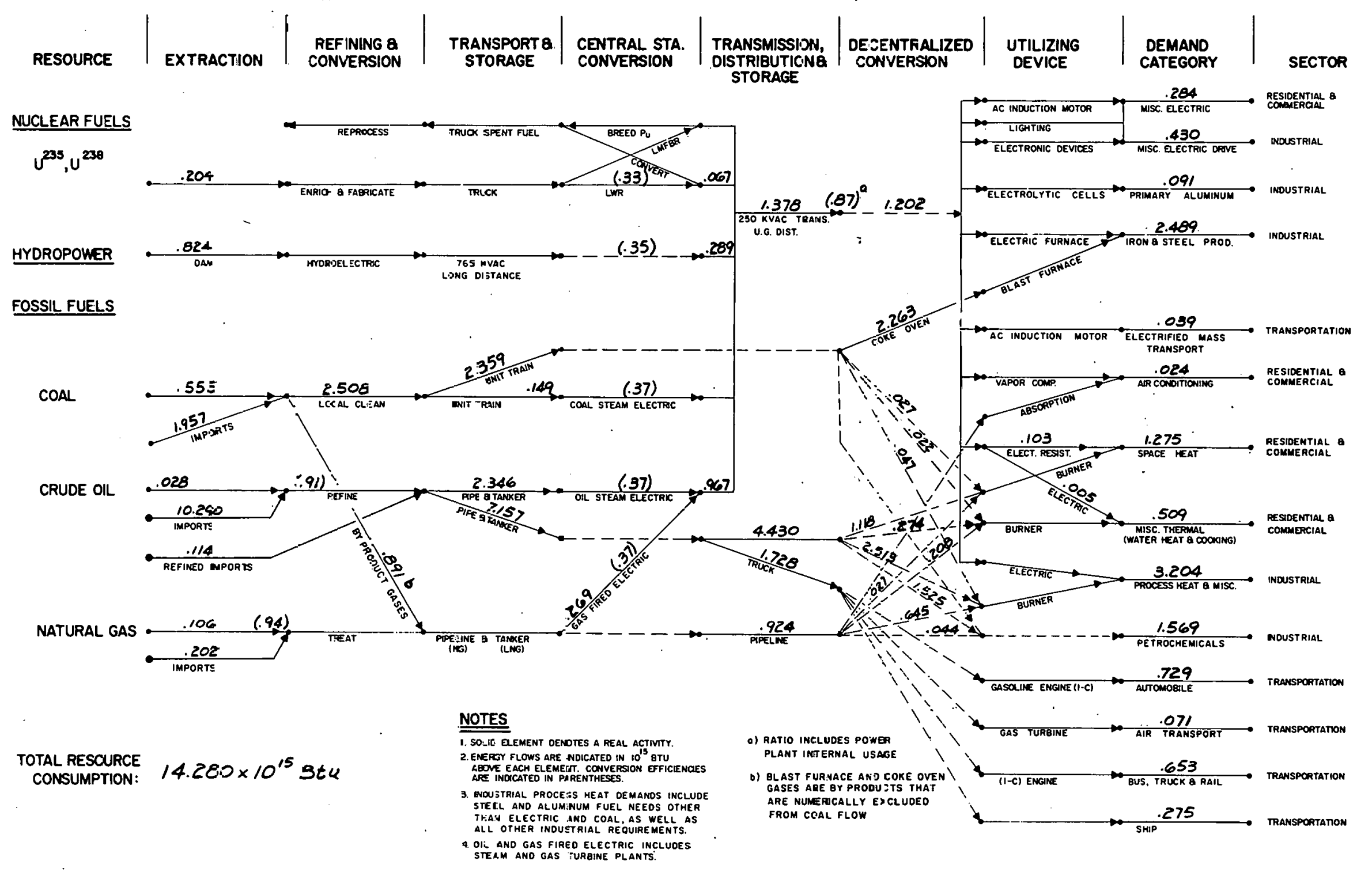

Figure S-1. Japan Reference Energy System, Fear 1974. 


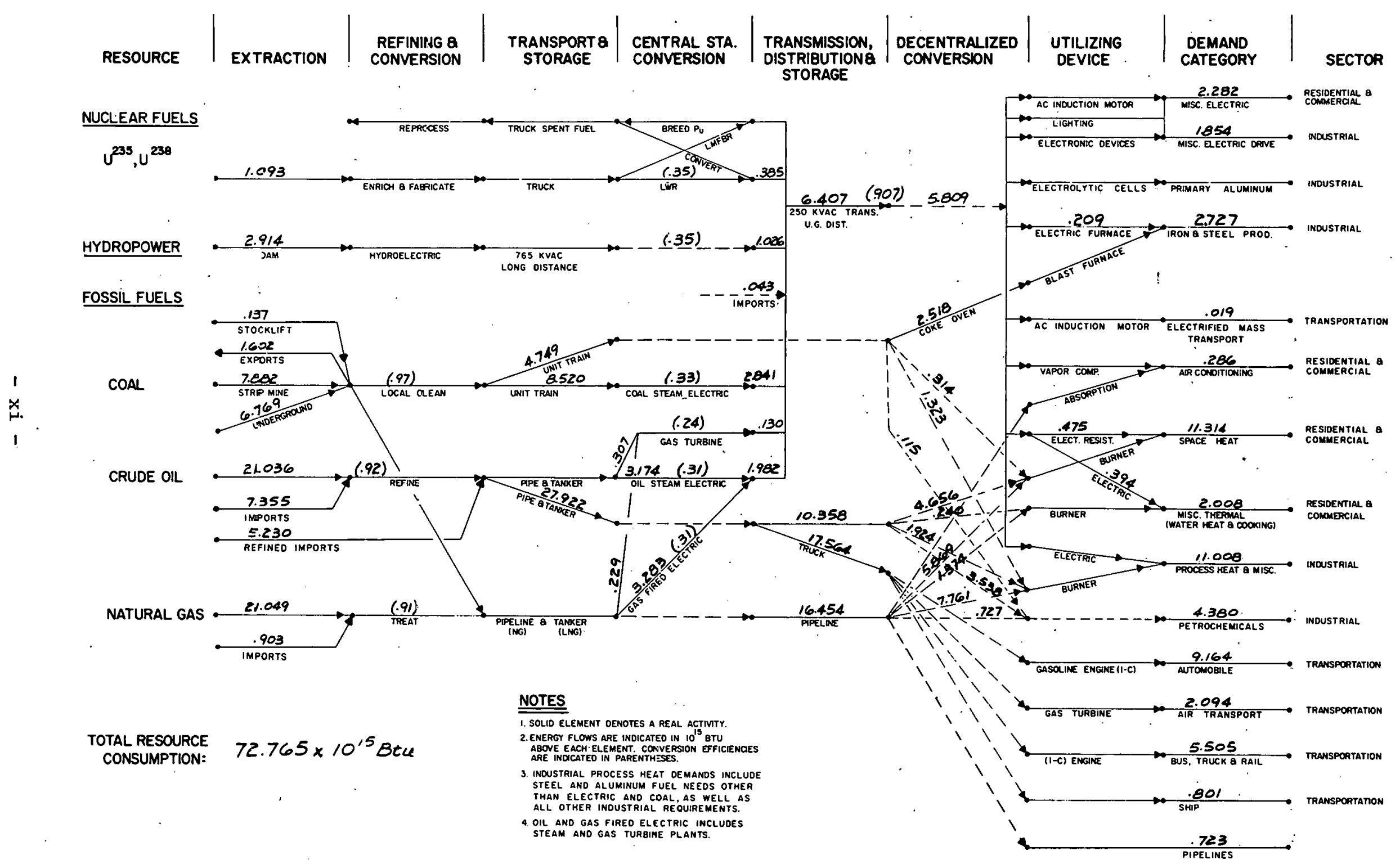

Figure S-2. United States Reference Energy System, Year 1974. 
and although still small, the contribution of nuclear power is projected to grow rapidly. Omitted from Figures $S-1$ and $S-2$ are the efficiencies of the end use devices usually incorporated in these Reference Energy Systems. 1

Per capita energy use for the residential sector is $27 \%$ of that of the United States, for transportation $19 \%$ and for industry $58 \%$. The differential in energy consumption for each of these sectors is shown in Figure S-3, and the elements that make up this differential have been roughly quantified and drawn into the bar charts representing United States energy use. These elements (Japan's larger use of passenger rail transportation, smaller consumption for spaçe heat, more efficient iron and steel industry, etc.) are all dealt with at length in the body of this report.

The impact of energy prices in the development of energy consumption patterns is unclear. Until 1973 Japan paid less than the United States for a barrel of crude, benefiting fully from the extensive world markets in the sixties, while the United States had import restrictions and higher priced domestic production. Except for historically expensive gasoline (retailing at $\$ 1.65$ per gallon in 1976) pre 1973 prices for pctroleum producls hive been practically identical to the United States prices. No taxes are levicd on heavy oil (the principal industrial fuel) and kerosene (used for space heating). 'lable S-1 summarizes these prices and tarcs for the 1970-1976 period. It has to be kept in mind, however, that while Japan is lueled nearly exclusively by oil, large segments of industry and households in the United States use natural gas which has been considerably cheaper than oil.

The prices for other fossil fuels are considerably more expensive in Japan. Coal prices on a heating unit bacis have historically been more expensive than fuel oil, and the dwindling domestic production is heavily subsidized 

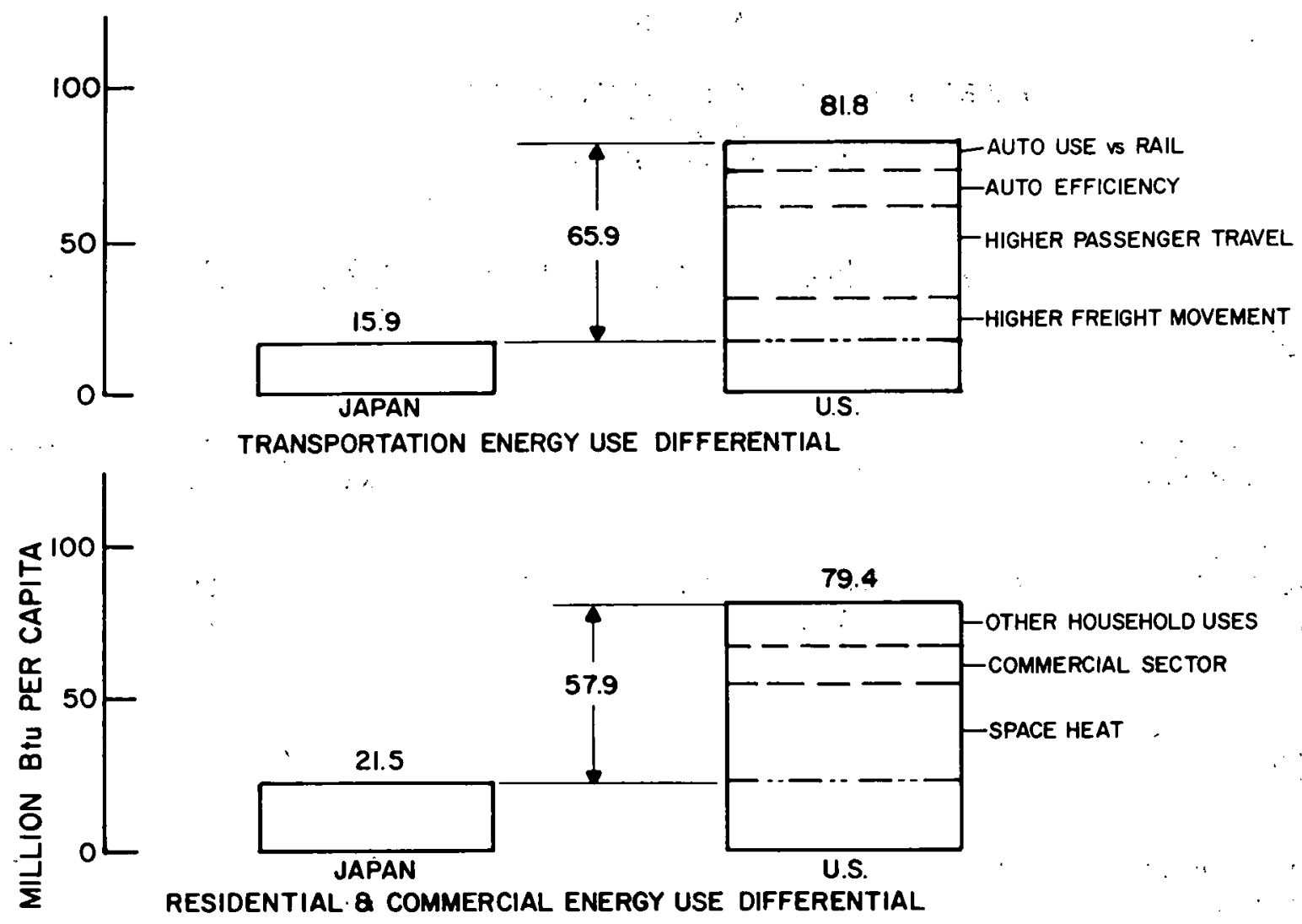

TRANSPORTATION ENERGY USE DIFFERENTIAL
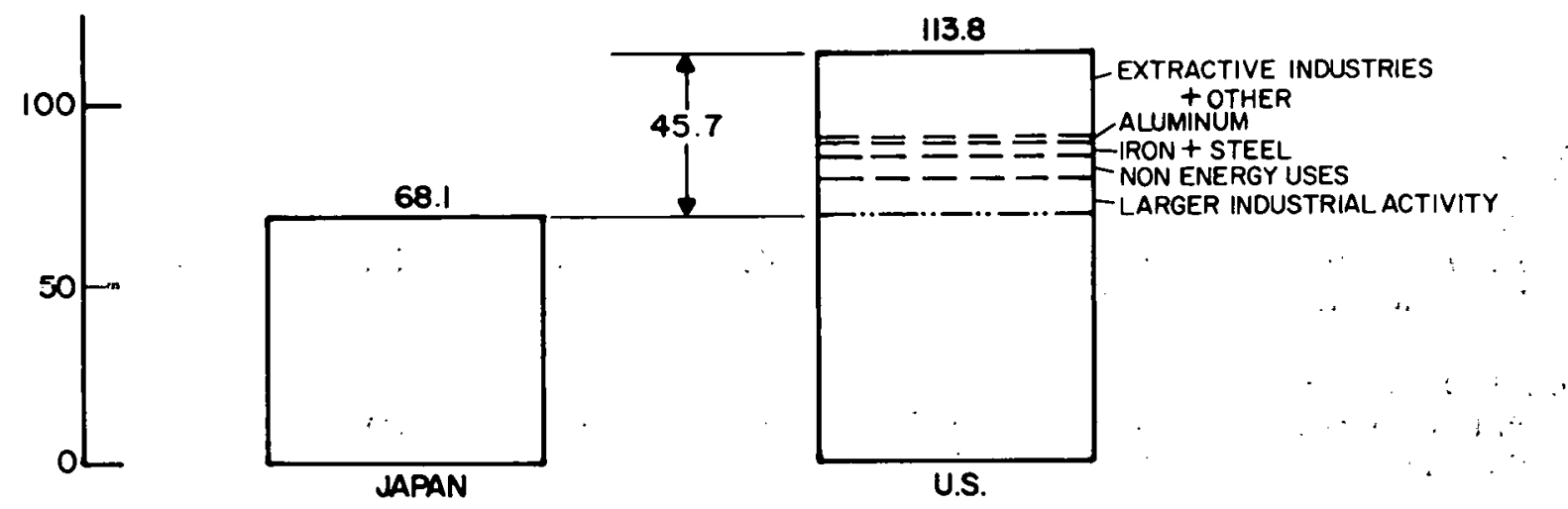

INDUSTRIAL ENERGY USE DIFFERENTIAL

Figure S-3. Sectoral Energy Differentials, Japan-United States. 
TABLE $S-1$

PRICES AND TAXES FOR PETROLEUM PRODUCTS ${ }^{1}$

1970-1976

(cents per gallon)

$\underline{1970} \cdot \underline{1971} \quad \underline{1972} \quad \underline{1973} \quad \underline{1974} \quad \underline{1975} \quad \underline{1976} \quad:$

GASOLINE

$\begin{array}{llllllrr}\text { JAPAN } & & & & & \\ \text { Retail Price } & 52 & 56 & 69 & 83 & \text { NA } & 129 & 165 \\ \text { Tax and Duty } & 33 & 33 & 38 & 42 & \text { NA } & 35 & 54 \\ \text { UNITED STATES } & & & & & & & \\ \text { Retail Price } & 36 & 40 & 40 & 40 & 53 & 56 & 59 \\ \text { Tax and Duty } & 13 & 13 & 12 & 12 & 12 & 12 & 13\end{array}$

KEROSENE

JAPAN

Retail Price 20

Tax and Duty 2

$23 \quad 27 \quad 30$

NA

0

48

NA

20

0

0

UNITED STATES

Retail Price

'I'ax and Duty

26

29

29

30

3.5

38

10

0

0

0

HFAVY DIL

JAPAN

Retail Price

'I'ax and Duty

$\begin{array}{rr}6.4 & 7.4 \\ .6 & .7\end{array}$

$8.6 \quad 11.3$

NA

NA

30.4
0

NA

UNITED STATES

Retail Price

Tax and Duty

4.0

8.7

8.4

8.7

0

NA

$\mathrm{NA}$

24.7

0

24.4

$\bar{I}_{\text {Data for }} 1970-73$ is from Rand Corporation. 20 Recent data is from Federal Energy Agency and Japanese Energy-Economic Institute. 
through tariffs collected on gasoline. Pipeline gas in 1974 (either manufactured from coal or LNG) was in the range of $\$ 6.50$ to: $\$ 7.13$ per million Btu 20 depending on use. Considering that only two decades ago coal still constituted half of the energy supplied, the relationship between energy prices and energy thrift could be viewed as a legacy of the time when expensive coal was the predominant fuel source. Electricity prices are difficult to compare because of the complex pricing schemes in both countries, but generally industrial prices have been historically comparable and residential rates much higher than in the United States. Recent price increases have fallen heavier on industry, weakening a policy favoring this sector. 20

The industrial sector emerges as the principal focus of interest in the study. Developing as an industrial giant since the post-war years with an average yearly growth rate of $10 \%$, Japan's plant capacity is invariably more up to date than that of the United States. Complementing this modernity is the almost total dependence on imports for both fuels and raw materials which by itself promotes thrift. The result is that it takes Japanese industry $84 \%$ of the energy used in the United States to make a ton of steel, $62 \%$ for a ton of cement, $82 \%$ for a ton of aluminum and $93 \%$ for a ton of paper. There are indications that the relative importance of a particular industry within the industrial mix in Japan is decisive in establishing the level of energy conserving practices. For the industrial sector as a whole, however, the measure of energy consumption in industry per dollar of GDP originating in industry does not disclose a clear picture in favor of Japan; the ratio is $23 \%$ lower than in the United States using purchasing power parity exchange for GDF, and is $12 \%$ higher for Japan using official exchange rates. What this ratio does 
indicate is that Japanese industrial output is at least as energy intensive as that of the United States.

Energy consumption levels outside industry are markedly different between the two countries. We are here searching for technological features that help explain these differences in consumption levels, but what emerges are differences linked to cultural and institutional roots on the one hand, and differences in what traditionally is called "standard of living" on the other. Automobile ownership in Japan is nine persons per automobile versus less than two in the United States, average housing size is $65 \%$ that of the United States according to official statistics (but probably even smaller) and central heating is virtually unknown. Cultural dissimilarities are reflected in the size of the service sector. In Japan institutions such as nursing homes and college campuses are practically unknown. The third factor influencing energy consumption is geographical and demographic. Population density ( 733 persons per square mile compared to $57^{\circ}$ in the United States) with a distribution predominantly along the coastal areas of the Japenese archipelago has a large impact on demand for transportation services. Per capita passenger miles travelled are $33 \%$ of the United States level and freight ton miles $26 \%$ (the latter excludes however the important international freight). This lower demand is clearly linked also to smaller capita income, but it is not possible to separate the effects of income from those of demographics. The choice of modes is drastirally different, with Japanese passenger miles travelled by rail 50\% higher than the ones travelled by automobile. In the United States, passenger travel by rail is insignificant. Téchnological factors that contribute to the per capita consumption differential are present but there are not many examples outside industry. It is 
not surprising to find that the automobile fleet in Japan performs $40 \%$ better than the United States average (19.8 mpg versus $13.8 \mathrm{mpg})$. The superb rail- : roads and extensive subway systems existing in most major cities are very . modern and enjoy high occupancies, yielding significantly lower Btu per passenger mile ratios. Energy conversion systems at the household level are less energy intensive in Japan but they would not be considered acceptable to United States homeowners. Stoves and room heaters. provide most of the space heat ( $13 \%$ of United States level), table-top burners are used for cooking with less than one third of the households having ovens (consuming $60 \%$ of the United States levels). Solar water heating units are growing at a fast rate and presently are installed in $3 \%$ of all households. Estimates of yearly use per household of other appliances are invariably. smaller with lighting at $30 \%$, refrigeration at $40 \%$ and color television at $50 \%$ of the Kwhr use of United States homes. Clearly the major reason in these cases, however, is size of appliances and. level of yearly use rather than differences in technological efficiency. Japan's dependence on imports of natural resources includes not only fuels but iron ore, lead, copper, lumber, cotton and wool, for all of which it is the world's largest importer. It imports nearly all its. wheat and soybeans, and $75 \%$ of its fish consumption originates in distant seas. Self sufficiency in rice, a staple in the Japanese diet, is achieved through government subsidy together with a ban on imports. Imports could possibly supply the market at half the price of the domestically grown rice, but this would bring about a collapse of the agricultural sector with all the social implications this would entall.

Exports are vital for the Japanese economy and the level of international trade is reflected by the level of direct and indirect energy consumption em- 
bodied in these exports, which amounts to nearly $15 \%$ of the total. There is nevertheless no large imbalance because some $12 \%$ of direct and indirect energy use is embodied in imports of non-energy products. For the United States, international trade represents a relatively small fraction of total GDP and the import and export of energy embodied in non-energy products is balanced. Multinational comparisons of energy use are valuable means for presentation of information concerning technological features in other countries. They provide inslghts on the effects of standard of living, population distribution, c1imate and cultural dissimilarities upon energy consumption levels. In this report we point out:

1) Energy consumption per ton of output is smaller in Japan for energy intensive industries, due in large part to the modernity of Japan's capital stock. Studies of "best practice" processes in the two countries should be pursued in detail.

2) Comparison of efficiency of use in personal consumption of energy emerges as a complex subject inextricably linked to income levels and cultura1. factors. Among the group of industrialized countries, the case of Japan offers the largest disparity compared to the United States; these variants are minimized when comparing, for example, Northern European nations and the United States. 


\section{INTRODUCTION}

Analysis of statistics of various countries indicate that most Western European countries and Japan seem to create as many goods and services, measured as Gross Domestic Product (GDP) per capita, as the United States while consuming considerably less energy. Attempts to explain this difference and possible lessons that could be transferred to the United States have triggered a series of studies on transnational energy consumption patterns. The first one prepared for ERDA used Sweden as a comparison. ${ }^{1}$ Sweden is the "ideal" subject inasmuch as its per capita GDP is the closest to the United States (and at current prices and exchange rates has surpassed it), has unique technological features such as district heat and a high rate of electrification, and lastly, enjoys a reputation as a model modern society. The country selected for this second study, Japan, is at the other end of the spectrum among industrialized nations. The per capita GDP is around one half of the United States (although total GDP is by far the second largest of the group of industrialized nations). Culturally, Japan is a mix between an old society different from that of the United States and a recently adopted one essentially patterned after that of the Western world. Important energy intensive sectors of industry, however, are at stages of development unparalled anywhere else but in the United States. Sections of this report dealing with nonindustrial energy use focus on: the manner in which the United States and Japanese populations use energy. The attempt here is to touch on the question of standard-of-living, and the underlying premise is that insofar as large humes, large applianres and large automobiles are a measure of a high standard, the United States clearly comes out at the top. Japan is especially well suited as a subject for this premise 
because the share of personal consumption of energy (in households and private transportation) is considerably smaller than in the United States. A part of this lower consumption, however, is linked to what is perceived to be a different.lifestyle and can be quite independent of what we are calling standard of living. These culture-rooted differences are hopefully made clear in the text. The study is organized by consumption sectors (residential, commercial, transportation and industrial), with a brief overview of the supply and electric generation situation in Japan. The largest effort is devoted to the comparison of spectific energy requirements for a group of energy intensive industries. Trnn and etecl, alumiumu, cement and paper are included. These comparisons point out areas of possible technological transfer, although specific recommendations would have to be left to industry specialists.

Lastly, the selection of a gross energy efficiency indicator for all of industry - such as energy use in industry per dollar of GDP originating in industry, brings out the issue of relevant currency exchange.rates. Vagaries in exchange rates have the effect of increasing or decreasing these efficiency ratios and as a consequence will render doubtful results. More importantly, official exchange rates do not necessarily reflect the actual domestic purchasing power of a sum of money. These difficulties are discussed in detail in the next paragraphs.

Measure of Gross Domestic Product. The most widely accepted measure of the economic output of a nation is the Gross Domestic Product* (GDP), and on a per capita basis the ratio has come to serve as a measure of standard of

\footnotetext{
*Gross Domestic Product (GDP), used by OECD and the United Nations among others, differs Irom the better known Gross National Product (GNP) only slight1y. GDP omits net factor income from abroad (remittances from residents living abroad, income from foreign investments) while GNP does not.
} 
living. Energy per capita ratios have also been considered as such a measure but this concept is being discarded because they convey no information on how efficiently this energy is being converted to provide goods and services. The best gross measure of this efficiency is energy consumption per dollar of GDP, and although this ratio depends greatly on the energy intensity of the indus- . trial mix of a country, it is considered useful.

Gross Domestic Product is obtained from the Organization for Economic Cooperation and Development (OECD), ${ }^{9}$ which lists the 1974 per capita GDP's in 1970 prices and 1970 exchange rates. These are arrived at by deflating the GDP's to the base year (in their respective currency) by the domestic rates of inflation and then applying the market or official exchange rates in effect in the base year (in our case 1970). These rates, as OECD emphasizes in its preface, "_... do not necessarily reflect the purchasing powers of currencies and may as a consequence distort intercountry comparisons of GDP and its.components." What this means is that an amount of United States dollars converted at the official exchange rate to Japanese yen will be able to purchase a different market basket of goods than the same amount of United States dollars in the United States. The following quote is from Kravis,. I., et al 10 "... United States $\$ 1000$, when converted to sterling at the official exchange rate, bought a basket of U.K. goods 64 percent larger than the dollars could have purchased in the United States." Development of a more meaningful measure of exchange rate which reflects real equivalence, in buying power was undertaken by Kravis 10 and in the case of United States vis a vis Japan they arrive at an "ideal" exchange (labeled "purchasing power parity," ppp) rate of 246 yen per dollar for 1970, versus the offjcial rate in 1970 of 360 . The effect of this is to increase the dollar amount of Japan's GDP by $46 \%(360 / 246)$ with respect to the 
United States GDP, which remains unchanged. This higher value is a better measure of the actual production/consumption per capita because it reflects "true" exchange rate parity and insofar as GDP is equated with satisfaction or standard of living, this revised GDP is presumably a better measure of this standard.

The numerical results of the discussion put forth above are shown in Table 1. In 1974 prices and exchange rates, Japan has a per capita GDP that is 62 percent of that of the United States, while this same amount expressed in 1970 prices and exchange drops to 44 percent. There are two factors that produce this difference, a higher internal inflation in Japan in the 1970-74 period and a drop in the value of the dollar versus the yen. An inflation deflator should not distort a measure of standard of living but a currency reevaluation does. Devaluation does not necessarily affect all domestic prices, thereby not changing standard of living, but the use of this new exchange rate will affect the GDP value converted to annther surrency. In gencral, most per capita GDP's for industrialized countries appear higher with rcopcct to the United States when expressed at current exchange rates for recent years, and for 1974 Sweden's appears higher than the United States'. When deflated to some past base year, the relationship between the United States and other countries changes drastically (Table 2). It is hard to relate this to what we are trying to measure here, standard of living. On the one hand, the more recent currency exchange rates are results of a floating system, as opposed to the fixed rate prevalent in 1970, thereby indicating an improvement from the old system. But it is not obvious how Sweden's overtaking the United States in GDP per capita between 1972 and 1974 relates to standard of living in those countries "before" and "after." 
TABLE 1

GROSS DOMESTIC PRODUCT PER CAPITA (U.S. \$)

\begin{tabular}{|c|c|c|c|}
\hline . & Japan & U.S. & $\begin{array}{c}\text { Fraction } \\
\text { Japan/U.S. }\end{array}$ \\
\hline 1974 GDP/CAP, 1974 prices and exchanges & 4,152 & 6,598 & .62 \\
\hline 1974 GDP/CAP, 1970 prices and exchanges & 2,294 & 5,262 & .44 \\
\hline Official 1970 Exchange Rate & & 358 yen $/ \$$ & \\
\hline "Ideal" 1970 Purchasing Power Parity & & 246. yen $/ \$$ & \\
\hline $\begin{array}{l}1974 \text { GDP/CAP, } 1970 \text { prices and ppp exchanges } \\
1974 \text { population }\left(10^{6}\right)\end{array}$ & $\begin{array}{r}3,338 \\
110.05\end{array}$ & $\begin{array}{l}5,262 \\
211.4\end{array}$ & .63 \\
\hline
\end{tabular}

TABLE 2

GROSS DOMESTIC PRODUCT PER CAPITA, SELECTED INDUSTRIALIZED COUNTRIES

\begin{tabular}{|c|c|c|c|c|c|c|}
\hline & & $\begin{array}{l}\text { Capita } \\
\text { nt pric } \\
\text { xchange }\end{array}$ & & & $\begin{array}{l}\text { Capit } \\
\text { Price } \\
\text { anges) }\end{array}$ & \\
\hline & 1972 & $19 / 3$ & 1974 & 1972 & 1973 & 1974 \\
\hline U.S. & 5,563 & 6,167 & 6,598 & 5,153 & 5,403 & 5,262 \\
\hline Japan & 2,750 & 3,765 & 4,152 & 2,161 & 2,344 & 2,294 \\
\hline Sweden & 5,153 & 6,199 & 6,878 & 4,188 & 4,330 & 4,500 \\
\hline $\mathrm{U} . \mathrm{K}$ & 2,791 & 3,112 & 3,371 & 2,274 & 2,393 & 2,410 \\
\hline Germany & 4,244 & 5,600 & 6,195 & 3,249 & 3,397 & 3,413 \\
\hline Canada & 4,840 & 5,485 & 6,464 & 4,247 & 4,485 & 4,538 \\
\hline
\end{tabular}


The study by Kravis ${ }^{10}$ is an effort to establish exchange rates that reflect actual purchasing power. For each item in the market basket of goods one parity was calculated based on local prices, and in such a way an "ideal" exchange rate applicable to Gross Domestic Product was arrived at for each pair of countries studied. This methodology effectively resolves the vagaries of official exchange rates that haunt international comparisons, but it still relies on the same measure of GDP as a measure of standard of living. The general effect of this revised GDP (ppp) is to increase the GDP of poorer countries with respect to the United States (the United States GDP remains numerically unchanged because the currenry used in the comparison is the Unfted states dollar). This makes the ratios of energy per dollar GDP sma1ler for these nations, i.e., in a comparison the United States appears to be using comparatively more energy per dollar GDP than with the commonly used (official exchange rate) values. 


\section{ENERGY SUPPLY}

The supply situation in Japan is drastically different from that of the United States. It is dependent on oil for nearly three quarters of its energy and essentially all of it is imported. Its indigenous production of 1 million tons is two tenths of one percent of its consumption, and no other fossil fuels are very abundant: indigenous coal totals $22 \%$ of coal consumption and natural gas only $1 \%$ of total energy (Table 3 ). The problem of energy supply is "... essentially one of oil supply, $"{ }^{2}$ and one of the objectives of Japan's energy policy is that of diversification of sources. This remains a problem, especially since all but $5 \%$ of their oil comes from OPEC countries. In the first half of 1976 these were Saudi Arabia (31.4\%), Iran (19.5\%), Southeast Asia (17.3\% - mainly Indonesia), and the Emirates (11.5\%). Their non-OPEC sources are Oman and China. ${ }^{3}$

The predominance of oil is a recent development. In 1955 coal constituted half of supplies and oil only $20 \%$, and as recently as 1960 coal was st111 the most important source. Such a rapid transition was aided by Japan's economic growth rate in the post-war period, by far the highest in the industrialized world at $10 \%$ per year. But rapid changes in supply configuration are not unknown in the United States either. In 1968, the share of imported oil was only $20 \%$ of the total, and by 1976 this share had more than doubled, to $42 \%$. This amount represents one and a half times the total Japanese oil imports, which shows the importance to worldwide trade of this increasing share of imported oil by the United States. Japan managed to keep oil consumption in 1975 only fractionally higher than in 1974, and for 1976 will show what is considered a very small increase of $4 \%$ despite economic recovery. Thus, strong 
TABLE 3

ENERGY SUPPLIES, $1974^{1}$

\begin{tabular}{|c|c|c|c|}
\hline \multicolumn{2}{|c|}{ Japan } & \multicolumn{2}{|c|}{ U.S. } \\
\hline $10^{12} \mathrm{Btu}$ & Percent & $10^{12} \mathrm{Btu}$ & Percent \\
\hline 555 & 4 & 13,048 & 18 \\
\hline 1,957 & 14 & -- & -- \\
\hline 28 & - & 18,556 & 25 \\
\hline 10,290 & 72 & 7,355 & 10 \\
\hline 114 & 1 & 5,230 & 7 \\
\hline 106 & 1 & 23,803 & 33 \\
\hline 202 & 1 & 903 & 1 \\
\hline 824 & 6 & 2,914 & 4 \\
\hline 204 & 1 & 1,093 & 2 \\
\hline 14,280 & & $73,0.1$ & \\
\hline
\end{tabular}

$1_{\text {Source: }}$ Reference 8 
feeling exists in Japan that world oil prices are linked to conservation efforts in the United States, because in recent years the United States is considered the major source of unrestrained demand on world markets. 3

The other energy sources in Japan are coal (18\%) used in the large iron and steel industry (half the metallurgical coal is obtained in the United States) and which provides two thirds of the town gas used for residential cooking, hydroelectricity amounting to $22 \%$ of the total generated and nuclear, which in 1974 represented $5 \%$ of total generation and by 1985 is projected to increase to $36 \%$. One other indigenous source besides solar heating is geothermal energy, which will generate $5 \%$ of the electricity by 1985 .

As can be seen by this brief overview, the supply situation in Japan has little to compare with the one in the United States, where at one point energy independence was considered a feasible goal. Japan relies mainly on its ability to secure sources of oil, with additional efforts in the development of nuclear, geothermal and solar resources.

Energy Prices: The price of oil is critical in establishing patterns on energy consumption in Japan. Its infrastructure was created before the 1973 embargo and, therefore, it is relevant to review the oil price situation prior to the increase.

The average price paid by Japan for a barrel of crude oil during the sixties and early seventies was significantly lower than the average price in the United States. In 1965 it was $\$ 1.98$ per barrel in Japan and $\$ 2.81$ per barrel in the United States; in $1970 \$ 1.80$ versug $\$ 3.12$ and in 197.3 the average was still $\$ 3.29$ for Japan and $\$ 3.60$ for the United States. 20 Japan benefited from rising world production at the time, while the United States had oil import quotas and a higher priced domestic production. Japanese domestic prices 
for pelroleum products are set by government policy and this policy has been one of favoring industry and the poorer segments of the population. Heavy oil (used by industry) and kerosene (used for space heating and lighting) are not taxed and up to 1973 were priced lower than similar products in the United States. ${ }^{20}$. The mix of fuels used for space heating in the United States, however, includes cheaper natural gas and is less expensive than the price for kerosene; the comparison here is clearly not on the basis of expense per household. The price of gasoline on the other hand has always been high in Japan (\$1.65 per ga11on in 1.976), much like in Western Europe. Taxes up to 1973 have been three times higher than United States taxes and in 1976 represented 33\% of the retail price (compared to $22 \%$ in the United States).

We could conclude then that energy thrift in Japan may be more a consequence of import dependence than of prices, but it may also be a legacy of the earlier dependence on coal. The price of coal has historically been higher than that of fuel oil (on heating unit basis), even though domestic production is heavily subsidized. The subsidy is funded from gasoline tariffs. Coking coal is all imported, and in 1971, the average price for these imports was $\$ 21.4$ per metric ton. 20 Distributed gas for home cooking is derived from coal or supplied by LNG and is also very expensive.

The price nf electricity is more dlfflcult to compare because of complex rate schedules and regional factors. Except for local situations where United States rates to industry are significantly lower than the national average, it appears that Japanese and United States rates to industry are closely comparable. $^{20}$ These ranged from 4.77 to 2.71 cents/kwhr in Japan in 1974 to 4.57 to 3.21 cents/kwhr in the United Stated in that year for commercial users and 3.00 to 2.61 cents/kwhr for large industrial users. ${ }^{21}$ It differs in that Japan has 
an extra low rate after midnight and a low rate for the subsidized agricultural sector. The residential sector is markedly higher in Japan and rates are not promotional in nature. Rates were in the range of 5.06 to 5.69 cents/kwhr in $1974^{20}$ (except for an extra low rate of 2.68 cents/kwhr for users of less than $120 \mathrm{kwhr}$ per month), while in the United States the scale is reversed, with users in the $1000 \mathrm{kwhr}$ per month range paying $\$ 2.49$ cents/kwhr in 1974 and users of leș than $100 \mathrm{kwhr}$ paying 4.99 cents/kwhr. 


\section{ENERGY CONSUMPTION BY SECTORS}

There are numerous ways to divide energy consumption among the three activity sectors: Industry, Transportation, and Household and Comercial. Data used here is obtained from the Reference Energy Balance Format (REBF) tables developed by the International Energy Agency's Systems Analysis Project'

during 1976 at Brookhaven National Laboratory. ${ }^{8}$ This data is collected in consistent fashion and there are few ambiguities in allocation among the three sectors. The results are summarized in Table 4, which shows a consumption of 129 million Btu per capita in Japan versus 345 million Btu in the United States. There are large differences in the breakdown among sectors. Japanese industry consumes three times as much energy as the transportation sector and two and a half times that consumed in the household and commercial sector. In the United States these three sectors consume energy at approximately equal levels. This difference points out the essential difference in consumption patterns becween the two countries. Personal consumption of energy, which takes up the largest pulliun of the energy consumed in the transportation and household and commercial scctors, is much smaller in Japan, and the following sections study these in detail. On a per capita basis, transportation consumes only $19 \%$ and household and commercial only $27 \%$ that of the United States. These large differenccs indicate more than end use efficiency differences and point out that the average United States consumer receives considerably more "lifestyle" (comfort, mobility, etc.) than the average Japanese. Consumption in industry, on the other hand, is much higher at $58 \%$ of United States per capita use which is cluse to the GDP per capita percentage. On a per dollar GDP originating in 
TABLE 4

ENERGY CONSUMPTION BY SECTOR, $1974^{1}$

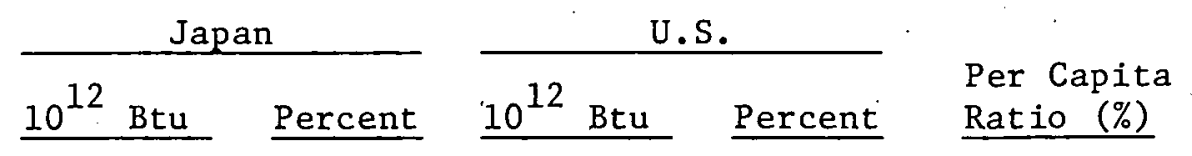

Residential and

Commercial ${ }^{a}$

$\begin{array}{lcccc}2,371 & 17 & 16,786 & 23 & 27 \\ 1,750 & 12 & 17,300 & 24 & 19 \\ 5,929 & 42 & 19,586 & 27 & 58 \\ 2,661 & 19 & 14,856 & 20 & 34 \\ 1,569 & 11 & 4,473 & -6 & 67 \\ 14,280 & 100 & 73,001 & 100 & \end{array}$

Population $\left(10^{6}\right)$

110.05

211.40

Per Capita

Energy $\left(10^{6}\right)$ Btu

129

345

37

${ }^{1}$ Source: Reference 8

ancludes military under commercial

$\mathrm{b}_{\text {Excludes bunkers }}$

${ }^{c}$ Manufacturing, including refineries, gas plants, and blast furnaces

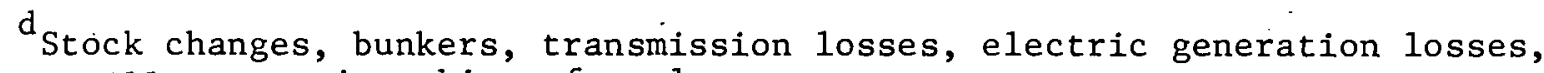
ancillary use in coking of coal

eptrochemicals, asphalts 
industry, Japan uses as much energy as the United States, which is a reflection of the energy intensity of Japan's mix. This ratio is covered in detail in Section III-2.

The data in Table 4 is compiled as follows: the "Other" category (comprising roughly the same share in both countries) consists of stock changes, bunker fuels, transmission losses, electric generation losses and statistical differences. Industry includes all manufacturing, petroleum refining, blast furnaces, gas wnrks and natural gas prucessing plants. Transportation excludes bunker fuel in shtps; and all military uses (whlch are included with commercial). Commercial also includes non-manufacturing categories not explicilly added to industry, such as agriculture, forestry and fisheries. This disaggregation differs slightly from the familiar one issued by the United States Bureau of Mines.

\section{III-1 ELECTRIC GENERATION}

Data on this sector are presented in Table 5 for Japan and the United States. The Japanese case is a reflection of its overall dependency on imported oil, which lepresents nearly two thirds of its fuels to electricity. The exception is the existence of a sizable amount of hydroelectricity totaling $22 \%$ of the total (measured in fuel equivalent). The futurp configuration is projected to change vastly with the introduction of imported 11quefied natura1 gas ( $18 \%$ by 1985 ) and an expansion of nuc.1ear ( $36 \%$ by 1985). This would drop oil not only in its percentage share but also in absolute quantity. The 1985 projections were obtained from the IEA Systems Analysis Project ${ }^{8}$ and are based on official Japanese sources. The overall growth rate in generation assumed is $6 \%$ per year. 
TABLE 5

ELECTRIC GENERATION，1974

Public Utilities

Fuels to Electricity

Coal

0i1

Gas

Hydro $^{\mathrm{a}}$

Nuclear ${ }^{a}$

Total

Electricity Distributed

Overall Efficiency ${ }^{2}$

Generation by Industry

Total Consumption per Capita
Japan

$10^{12}$
2,346
$269^{1}$

825

$\underline{204}$

3,793

1,203

.317

188
U.S.

\begin{tabular}{cr}
\hline $10^{12}$ Btu & Percent \\
8,520 & 44 \\
3,481 & 18 \\
3,512 & 18 \\
2,914 & 1.5 \\
1,093 & 6 \\
19,520 & 100
\end{tabular}

5,809

.298

350

${ }^{\mathrm{a}}$ Expressed as fuel equivalent ( $9700 \mathrm{Btu} / \mathrm{Kwhr}$, or .352 efficiency)

${ }^{1}$ Some $50 \%$ is blast furnace gas

2 This efficiency has several implicit aspects. Thermal power plants are rated at $37 \%$ effiriency by Japanese sources. The calculation includes as output the electricity consumed by power plants; U.S. sources report net output from power plants. This internal use is about 5\% of total generation, based on Western European and Japanese data. Adjusting Japan's data yields $35 \%$ efficiency versus an average of $32 \%$ for the U.S. The use of gas turbines at $25 \%$ efficiency contributes to this difference; it is also likely that Japan's stock is more modern. Distribution losses are similar, 9-10\%. 
On a per capita basis, Japan consumes $43 \%$ of the United States level, compared with $63 \%$ for GDP per capita, indicating a slightly smaller rate of electricification in Japan. One notable difference between the two systems is the large proportion of electricity generated by industry (13.5\% vs. $5.6 \%$ ). This is also true for countries like Sweden and Western Germany, which cogenerate most of their industrial electricity jointly with steam required for processes, and sell the surplus electricity. In Japan, besides conventional selfgeneration schemes there are unique arrangements whereby several industries mutually contract for central power plants built to serve them exclusively. Nuclear installations also exist under this arrangement. These "kndo karyoku" plants, however, cogenerate only part of their steam and power. Data on installed generating capacity, Table 6 , shows that Japan had $879 \mathrm{kw}$ installed per thousand population in 1973, while for 1974 the United States ratio was $2343 \mathrm{kw}$.

\section{III-2 INDUSTRIAL SECTOR}

Japan's industrial production is the second largest of the Industrialized nations, and tor one of the important energy users, pig iron, its output can surpass that of the United States. The industrial sector is thus ideally suited for a meaningful comparison. It is here where technology trangfer is must feasible and statements on conversion efficiency of an industrial activity in one country relative to the other are possible. Fresented in this report are specteic energy requirements for a group of energy intensive industries (iron and steel, aluminum, cement, paper) and as much data on unique technological features are included as were available. It.io felt, thougl, that chese briet 
TABLE 6

\section{INSTALLED ELECTRIC GENERATING CAPACITY}

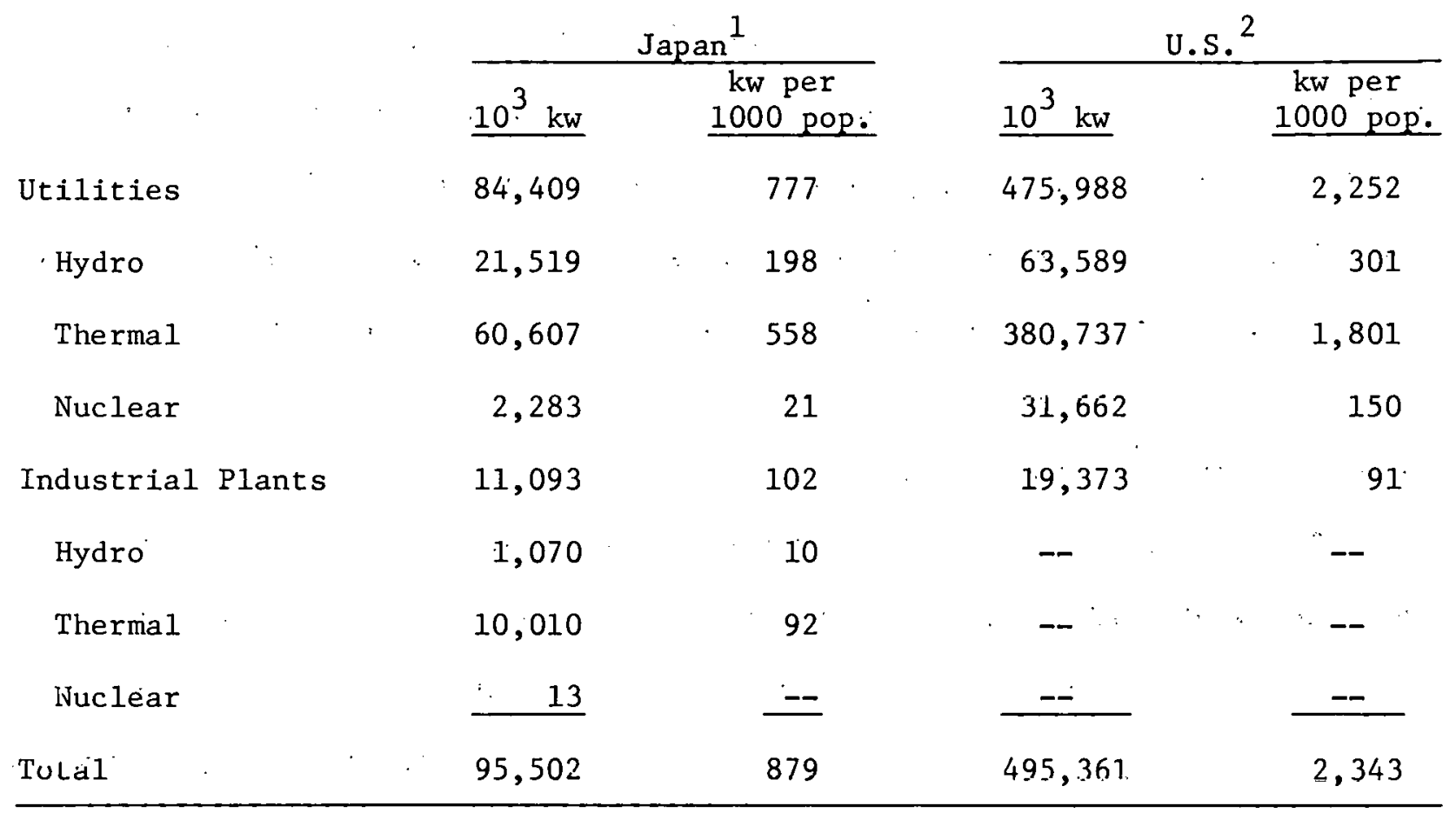

${ }^{1}$ Data for Japan is for 1973 from Reference 15.

2 Data for the U.S. is for 1974 from Edison Electric Institute, "Statistical Yearbook 1974." 
intercountry comparisons by industry are merely introductory to more detailed analysis that would be required for suggestions on technology transfer.

Another approach for comparison is pursued here, that of aggregate ratios such as energy per dollar of Gross Domestic Product originating in industry. Such a ratio together with observations on the relative energy intensities of the industrial mix of goods provides a valuable measure of efficiency of energy use. This ratio is computed in the following paragraphs, and while there are many caveats to the figures used, they are hopefully spelled out in the text.

\section{III-2-1 Énergy Use in Industry}

The collection of data for this sector was carefully assembled to insure consistency of definition. It contains all manufactures encompassed by the United States Standard Industrial Classification (SIC) groups 20 through 39 (International SIC Nos. 31-39), which include oil refining but not gas processing, and all energy related to the iron and steel industry i.s included except the ancillary fuel for coking coal. Consumption of fuels for non-energy purposes is also added thereby making the construction sector part of our definition of industry (because asphalt is included in the non-energy category).

The United States data is obtained for manufacturing industries from the Bureau of the Census Annual survey ${ }^{5}$ except for iron and steel for which the Statistical Report from the industry was used. ${ }^{\mathcal{O}}$ Use in petroleum refineries is taken from the Bureau of Mines, ${ }^{7}$ and the Census Bureau, ${ }^{5}$ with some adjustments. The data is presented in Table 7, including all non-energy uses of fuels (feedstocks, asphalt, etc.). Also included are the totals cited by the Bureau of Mines ${ }^{7}$ as fuels to industry, and it shows that a fraction of fuels are not accounted for. This accounts in large part for the difference between 
TABLE 7

U.S. ENERGY CONSUMPTION IN INDUSTRY, ${ }^{a} 1974$

\begin{tabular}{l}
\multicolumn{1}{c}{ SIC } \\
\hline 20,21 \\
24,25 \\
26 \\
28,30 \\
32 \\
$331-332$ \\
$33 \mathrm{NCE}$ \\
$34,35,36$ \\
37 \\
29
\end{tabular}

Food

Wood \& Lumber

Pulp \& Paper

Chemicals \& Plastics

Stone, Clay, and Glass

Iron \& Stee $1^{b}$

Non-ferrous metals

Machinery

Transport Equipment

Other

Refineriesc

Non Energy Use

Total Use in Industry

Natural Gas Processing $d$

Bureau of Mines ${ }^{f}$

\begin{tabular}{|c|c|c|c|c|c|}
\hline Oil & $\begin{array}{l}\text { Coal } \\
\text { Coke }\end{array}$ & $\begin{array}{c}\text { Natural } \\
\text { Gas } \\
\end{array}$ & $\begin{array}{l}\text { Other } \\
\text { Gas }\end{array}$ & $\begin{array}{c}\text { Purchased } \\
\text { Electricity }\end{array}$ & Total \\
\hline 145 & 69 & 491 & - & 136 & 841 \\
\hline 48 & 16 & 99 & - & 68 & 231 \\
\hline 480 & 187 & 446 & - & 147 & 1,260 \\
\hline 343 & 332 & 1,764 & - & 516 & 2,955 \\
\hline 132 & 223 & 713 & $\cdots$ & 104 & 1,172 \\
\hline 249 & 2,027 & 705 & 809 & 221 & 4,011 \\
\hline 43 & 38 & 384 & - & 327 & 792 \\
\hline 99 & 47 & 479 & - & 273 & 898 \\
\hline 43 & 45 & 147 & - & 102 & 337 \\
\hline 138 & 98 & 189 & - & 189 & 614 \\
\hline 1,897 & -- & 1,175 & -- & 93 & 3,165 \\
\hline 3,771 & 221 & 767 & -- & - & 4,759 \\
\hline 7,388 & $4,112^{e}$ & 7,359 & $809^{e}$ & 2,176 & 21,035 \\
\hline- & -- & 1,614 & -- & -- & -- \\
\hline 7,664 & 4,197 & 10,058 & -- & 2,665 & 24,584 \\
\hline
\end{tabular}

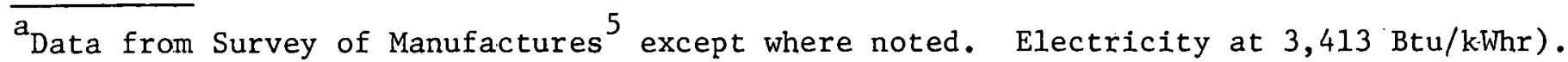

$\mathrm{b}_{\text {Iron \& Stee1 Institute. }} 6$

$\mathrm{c}_{\text {Data from Bureau of Mines }}{ }^{\top}$ and Survey of Manufactures ${ }^{5}$ with adjustments.

$\mathrm{d}_{\text {Calculated at }} 6.5 \%$ of procuction.

${ }^{\mathrm{e}}$ Gases from coal are summed with Coal and Coke.

f Includes use for fuel and power, and feedstocks. 
this total and the one used in Table 4 which was derived from the supply side.

Data for Japan ${ }^{8}$ is presented in Table 8 under the same breakdown of industries as the United States data. The best possible consistency between Tables 7 and 8 was obtained.

This compilation of industrial energy includes by-product fuels such as blast furnace gas but omits by-product fuels generated and used by the pulp and paper industry. The coking activity is not included because in the case of Japan, the by-product coke oven gas is only partly used by the iron and steel industry and a sizable fraction is sold as town gas or burned in power plants. In the United States, all by-products are used by the iron and oteel industry. The actual energy use in the coking of coal is small because byproducts (coke gas and coal chemicals) are utilized.

Gross Domestic Product Originating in Industry: National accounts disaggregate GDP by economic activity: agriculture, mining, manufacturing and so on. The best match with the industrial energy consumption is obtained by using GDP originating in construction and industry. The latter includes all manufacturing activities. Construction is included bccause a large fraction of the feedstocks added to industrial energy is asphalt used in this category. The energy used as fuel in the construction sector is very small and can be ignored. Energy used in natural gas prosessing in the Unitcd Statis is lefe out because this activity falls under Mining and Extraction.

For Japan, the portion of GDP originating in industry and construction is 46 percent and for the United States 30 percent. $^{i \perp}$ The difference is not surprising in light of Japan's proportionally larger industrial sector and the larger conuerclal sector in the United Statca. In boll cuuntries the time trend is towards a smaller share of industrial component of GDP. 
TABLE 8

JAPAN, ENERGY CONSUMPTION IN INDUSTRY, ${ }^{a} 1974$

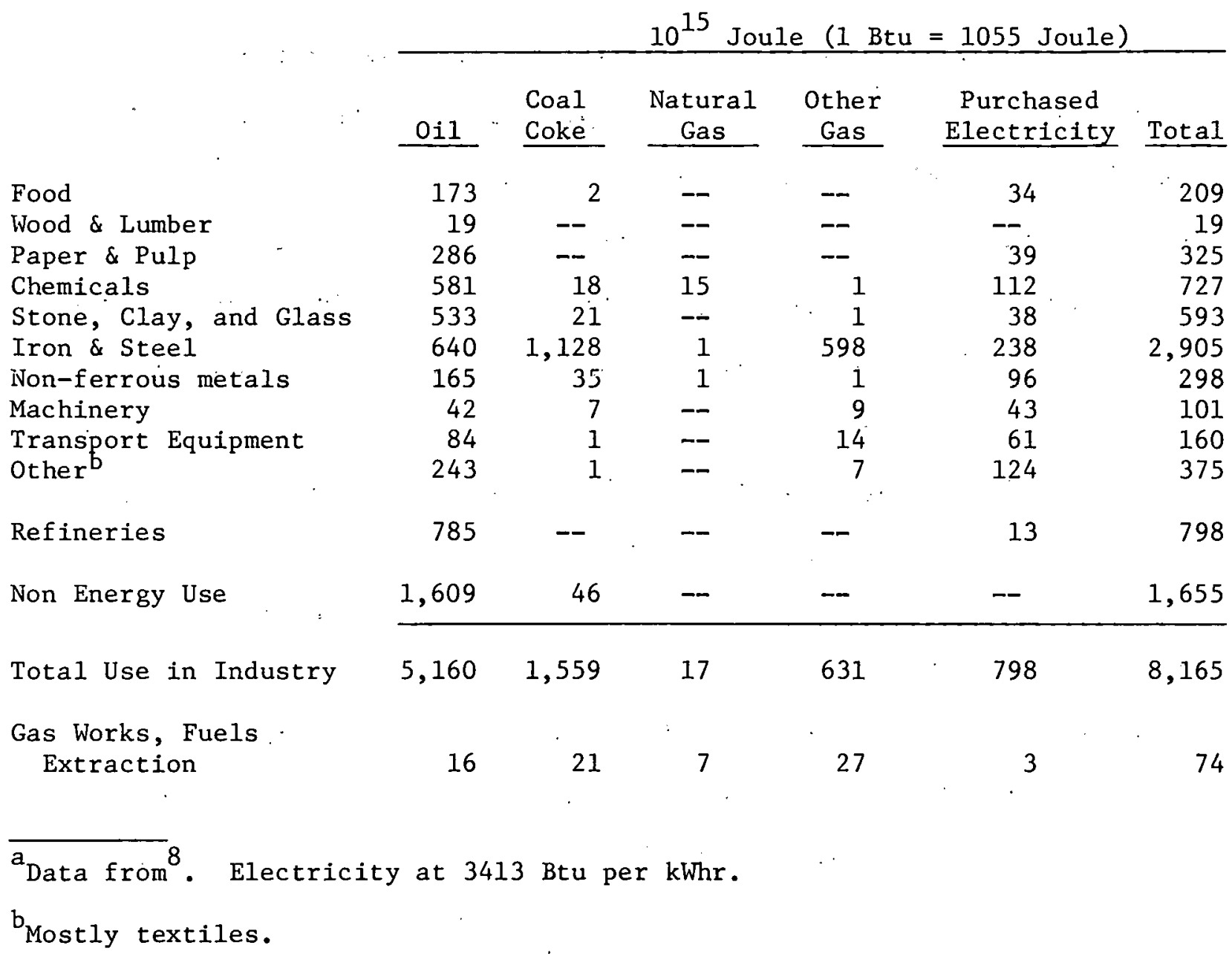


Energy per GDP Originating in Industry: The ratios of energy/\$GDP originating in industry for Japan and the United States are presented in Table 9, based on the energy usage in industry shown in Tables 7 and 8 and the GDP figures in Table 1. The results are inconclusive. Using purchasing power parity exchange, the ratio is $45,793 \mathrm{Btu} / \$$ for Japan and $59,748 \mathrm{Btu} / \$$ for the United States, for a ratio of .77 . By using official market exchange the situation is reversed, with Japan's ratio now larger at $66,601 \mathrm{Btu} / \$$. As a result, one set of figures imply that Japan is generating industrial GDP 23\% more energyefficiently than the United States, and another set would show that the reverse is true by $11 \%$. This confirms the tentative and also perverse nature of multinational comparison using an aggregated approach. The following paragraph shows that the relative energy intensity of the mix of industrial output does not bias this ratio either; Japan's industrial mix is no less energy intensive than that of the United States.

Energy Intensity of the Industrial Mix: It is true for most economies that the bulk of industrial energy is consumed by a small group of industries. In Lhe Un1ced States, the six largat (iron and steel, petrolemm refining, chcnLuals, pulp and paper, stone, clay and glass and non-ferrous metals) consume. 75\% of the total. In Sweden, two industries (paper and primary metals) consume $60 \% .^{1}$ In this respect, Japan is no different than Sweden. Thrce industries (iron and steel, chemira1s and rafincrica) consume uver cwo thirds of Industrial energy, and the same six that consume $75 \%$ of the total in Lhe Unfeed SLutco consume U6.J\% In Japan. I'able 10 details their distribution. From this list, it can be seen that the most worthwhile comparative analysis between these two countries (having technology transfer in mind) would bc based on studies of these industries. Covered in this report are iron and steel, alum- 
1974 GDP, 1970 prices and exchange rate $\left(10^{9} \$\right)$

1974 GDP, 1970 prices and ppp exchange $\left(10^{9} \$\right)$

$1974 \mathrm{GDP}$, (official rate) originating in industry ( $10^{9} \$$ of 1970$)$

$1974 \mathrm{GDP}$, (ppp) originating in industry $\left(10^{9} \$\right.$ of 1970)

Energy Consumed in Industry $: 10^{12} \mathrm{Btu}$ )

Energy per \$ GDP (official rate) in industry (Btu)

Energy per \$ GDP (ppp) in industry (Btu)
Fercent originating in industry \& construction ${ }^{(2)}$.

\begin{tabular}{cccc} 
Japan & & U.S. & Fraction \\
\cline { 1 - 1 } 252.5 & & 1112.3 & \\
367.3 & & 1112.3 & \\
$46 \%$ & $30 \%$ & \\
116.2 & 333.7 & \\
169.0 & 333.7 & \\
7,739 & 19,938 & \\
66,601 & 59,748 & 1.11 \\
45,793 & 59,748 & .77
\end{tabular}

(1) GDP from $\mathrm{OECD}^{9}$; Purchasing Power Parity exchange from Kravis ${ }^{10}$; Energy data from Table 5 and Table 6.

${ }^{(2)}$ United Vations Statistical Yearbook, 1974, data here is for $1973^{11}$. 
TABLE 10

MAJOR USERS OF ENERGY IN INDUSTRY ${ }^{1}$

\begin{tabular}{|c|c|c|}
\hline & \multicolumn{2}{|c|}{ Percent of Total Use } \\
\hline & Japan & $\mathrm{U} . \mathrm{S}$. \\
\hline Iron \& Steel & 44.5 & 22.2 \\
\hline Refineries & 12.2 & 17.7 \\
\hline Cliemicals & 11.1 & 16.6 \\
\hline Subtotal, top three & $67.8 \%$ & $56.5 \%$ \\
\hline Pulp \& Paper & 5.0 & 7.1 \\
\hline Stone, Clay, \& Glass & 9.1 & 6.6 \\
\hline Non-ferrous Metals & 4.6 & 4.4 \\
\hline Subtotal, top six & $86.5 \%$ & $74.6 \%$ \\
\hline
\end{tabular}

$\overline{1_{\text {Excludes }}}$ non-energy use, data from Tables 7 and 8 
inum (dominates non-ferrous metals), pulp and paper, and cement (dominates stone, clay and glass). Chemicals are omitted because this category consists of thousands of products ranging from rubber to fertilizers in which none clearly presents itself as an interesting choice for comparison. Refineries are also omitted because the data available is unclear on the large input of byproduct fuels in this industry. In addition, average energy consumption per barrel would be inadequate in this category because the mix of products is quite dissimilar. In the United States over two thirds of the production are light products (mainly gasoline), while in Japan two thirds of the production are heavy oil products.

The relative energy intensity of the mix of industrial goods is comparable between the two countries. Measured as yearly production per capita, one set of particularly energy intensive products, steel and cement, is greater in Japan, while production in the United States is larger in another group that is also very energy intensive, aluminum and paper. Table 11 presents a list of selected industry outputs for 1973. The large steel production in Japan is reflected in the large fabricated metals sector (vessels, motor vehicles, electronic equipment), even though a sizable fraction of it is exported. The textiles industry, albeit not energy intensive, is larger in Japan than in the United States. The chemical industry linked to agriculture (ammonia, fertilizer) is larger in the United States, while plastics production is comparable.

\section{III-2-2 Comparison of Specific Energy Requirements}

The four industries presented in this section, steel, cement, aluminum and paper, were selected on basis of their energy intensities, their size. within the industrial mix of products and the homogeneity of product that per- 
TABLE 11

$\underline{\text { PRODUCTION OF INDUSTRIAL GOODS, } 1973^{1}}$

$\quad \begin{aligned} & \text { (Metric tons per } 1000 \text { pop. } \\ & \text { except where indicated) }\end{aligned}$
Man-made Fabrics
Wood Pulp
Paper
Rubber
Tires (units per 1000 pop.)
Ammonia
Nitrogenous Fertilizers
Hlastics and Resins
Oxygen Gas (billion cu. ft. per 1000 pop.)
Cemcnt
Pig Iron and Ferro-alloys
Crude Steel
Aluminum, Primary
Aluminum, Secondary
Refined Copper
I.V. Sets (units per 1000 pop.)
Merchant Vessels (gross tons per 1000 pop.)
Motor Vehicles, passenger (units per 1000 pop.)
Motor Vehicles, commercial (units per 1000 pop.)
1 Source: l!nited Nations 11

\begin{tabular}{cc} 
Japan & U.S. \\
\cline { 1 - 1 } 17. & 16. \\
93. & 210. \\
147. & 253. \\
9.5 & 13.6 \\
776. & $1,071$. \\
37. & 66. \\
20. & 44. \\
59. & $57 .(1972)$ \\
3.1 & 1.9 \\
719. & $3 / 2$. \\
847. & 449. \\
1998. & 657. \\
10. & 20. \\
5.0 & 4.5 \\
9. & 10. \\
133. & 51. \\
144. & 4. \\
41. & 46. \\
24. & 14.
\end{tabular}


mits a meaningful comparison. A few salient features emerge from the analysis. Most important is the modernity of the Japanese industrial capacity relative to that of the United States, which translates especially for these energy intensive industries into lower average specific energy requirements. These newer installations are simply due to the extraordinary expansion of Japanese industry starting from a relatively small base after World War II. Pre-war industrial capacity was largely destroyed. Secondly, a search for energy efficient processes is always a priority in a resource poor country, or conversely, it is generally true for United States industry that usage of formerly plentiful natural gas is accompanied by relatively large specific energy use.

The largest difference in specific energy demand occurs in the two industries which are relatively larger in Japan, steel and cement. On the other hand in aluminum and paper, which are not industries that loom exceptionally high in Japan's product mix, specific energy use is quite comparable to that of the United States. This logical state of events could possible be extrapolated to industries not covered in this report; the energy per GDP ratio developed earlier seems to support this statement also.

\section{Iron and Steel Industry}

The iron and steel industry is without doubt the most important achievement of modern Japan's industry. With a capacity as large as that of the United States, it consumes $44 \%$ of the total energy in the industrial sector. Together with all other steel intensive industries such as transport equipment and machinery, it comprises $45 \%$ of the total value of shipments by manufacturing (Table 12). In the United States, the latter figure is 39\%. In 1974 Japan produced 99.6 million tons of pig iron and 129.1 million tons of raw steel; the United States in the same year produced 95.9 million and 145.7 million tons 


\begin{tabular}{|c|c|c|}
\hline r & $\therefore$ Japan & U.S. \\
\hline & $10^{9}$ yen & $10^{6}$ dollars \\
\hline Iron and Steel & 6,246 & 30,768 \\
\hline Fabricated Metals & 3,925 & 42,046 \\
\hline Machinery exc. Electric & 6,993 & 55,560 \\
\hline Electrical Machinery & 7,517 & 49,168 \\
\hline Transport Fquipment & 8,147 & 86,920 \\
\hline Total Manufacturing & 72,895 & 670,971 \\
\hline Percent, Five Industries & 45.1 & 39.4 \\
\hline
\end{tabular}


respectively. Annual production however is quite sensitive to economic trends and outputs fluctuate accordingly. Japan has the single largest integrated steel mill in the world and is the giant in world trade. It exported $23 \%$ of its production of steel products in 1973 and large fractions of the rest are embodied in exports of other goods such as automobiles and vessels. The United States imported 6.7 million tons of steel from Japan in 1974, out of 18.0 million total imports. On the other hand the United States exported 3.0 million tons of scrap to Japan, which is an indication of the relation between domestic production and final consumption (and scrappage) in the two countries. Data for this introduction was obtained from the United States and Japan Statistical Abstracts $^{15}$ and from the Annual Statistical Report of the American Iron and Steel Institute. 6

Inputs to Blast Furnaces: Figure 1 shows diagrams for specific energy and materials requirements to blast furnaces per ton of pig iron produced. Data for Japan is from $^{13}$ and for the United States from. ${ }^{6}$ It can be seen that Japan uses 0.441 tonnes of coke per tonne of pig iron produced versus 0.609 ton/ton for the United States. This lower use of coke is a characteristic of Japan's steel industry, even though in the United States the trend has also been steadily decreasing (in 1947 the ratio was $0.963 t / t$ ). The use of coke is replaced by higher injections of hydrocarbons and oxygen. Figure 1 shows oil inputs of 1.960 million Btu's per ton of pig iron in Japan, and only 1.086 million Btu of oil and natural gas in the United States. Inputs of oxygen are significantly higher for Japan.

The possibility of substitution between hydrocarhons and coke in the iron and steel industry in Japan is shown in Table 13, which indicates that since the 1973 price rise in oil (and the experience of vulnerability in supply), 
TABLE 13

JAPAN IRON AND STEEL INDUSTRY, COKE AND OIL INPUT PER TONNE OF RAW STEEL

Year

1972

1973

1974

1975
Coke

$\mathrm{Kg} /$ tonne

390

393

413

441
Heavy 011

lt/tonne

124

113

102

88

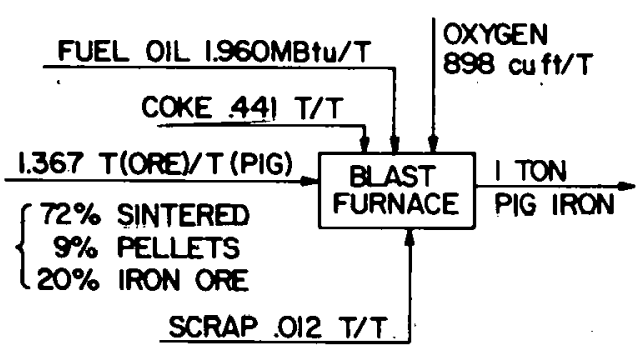

JAPAN

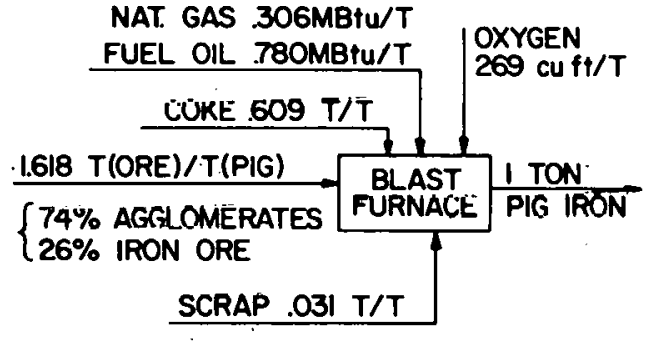

U.S.

Figure 1. Inpute to blast furnaces, 1974. 
use of coke has increased by $13 \%$ while use of oil has decreased by $29 \%$. While part of the increase in use of coke can be ascribed to diseconomies of scale (both 1974 and 1975 were recession years and production was considerably under capacity), $441 \mathrm{~kg} /$ tonne is the largest coke input since the early sixties; it thus clearly indicates higher coke usage. About one half of it is imported from the United States. The figures in Table 13 are obtained from ${ }^{17}$ and represent total coke and oil input to the industry.

Inputs to Steelmaking: The infrastructure of steel production is quite different in the two countries and is a reflection of Japan's modernity. In the United States in 1974 open hearth furnaces still produced $24.3 \%$ of the total steel, compared to only $1.3 \%$ in Japan (Table 14). The predominant process in Japan in the Basic Oxygen Furnace at $81.2 \%$ of production, versus $56 \%$ for the United States. Electric furnaces have approximately equal shares.

TABLE 14

STEELMAKING BY PROCESS, PERCENT, 1974

$\begin{array}{lcc} & \text { Japan } & \text { U.S. } \\ \text { Open Hearth } & 1.3 & 24.3 \\ \text { Basic Oxygen } & 81.2 & 56.0 \\ \text { Electric } & 17.5 & 19.7\end{array}$


All three steelmaking processes require oxygen imput, and these requirements vary significantly between the two countries (Table 15). Data for Japan is from $^{13}$ and for the United States from. ${ }^{6}$ The oxygen is produced by air separation and Japanese data show a requirement of 18,000 to $29,000 \mathrm{kwhr}$ of electricity per million cu. ft. of oxygen. The gas is not necessarily all manufactured internally by the steel industry however.

Total Input, Iron and Steel Industry: A summary of total energy consumption per ton of raw steel is presented in Table 16. The source for the United States data for this table is Rosen $^{14}$ and for Japan they are ${ }^{17}$ and ${ }^{13}$.

The smaller use of coke by Japan hao bcon discussed earlier (besides blast furnaces, coal is used only in the agglomeration of iron ore). Electricity is used more intensively in Japan, 1.95 million Btu (e) per ton versus 1.31 million Btu (e) per ton. This is due to the configuration of the steelmaking process used and the manufacture of large quantities of oxygen gas. Expressing electricity input in terms of primary equivalent (by multiplying by 3.0) yields a total consumption of 21.29 million Btu per ton for Japan and 25.32 militinn ktu per ton for the Uiiled stures. 'Lhe dififerences is almost entirely in the use of coal. There is, however, an addit1onal energy savings in the case of Japan that lies hidden due to acrnunting convention. An indem terminate fraction of the by=product gases (coke uven and blast turnace gases) die used as fuel by the kudo karyoku, power plants which appear as purchased elcctricity. This explains also the relatively small use of these gases by the industry when compared to the United States figures. That portion of this electricity should be accounted under self generated power. We can conclude then that Japanese steel is manufactured with less than $84 \%$ of the primary energy requirements of steel manufactured in the United States. 


\section{. OXYGEN REQUIREMENTS, CU-FT PER TON OF RAW STEEL}

$\begin{array}{lrr} & \text { Japan } & \text { U.S. } \\ \text { Open Hearth } & 453 & 1,344 \\ \text { Basic Oxygen } & 1,639 & 1,924 \\ \text { Electric } & 770 & 279\end{array}$

TABLE 16

ENERGY INPUT, IRON AND STEEL INDUSTRY

(MILLION BTU PER TON OF CRUDE STEEL)

\begin{tabular}{|c|c|c|c|}
\hline & $\begin{array}{r}\text { Jap } \\
(1974 \\
\end{array}$ & $\begin{array}{l}\text { pan } \\
\text { Data) } \\
\end{array}$ & $\begin{array}{l}\text { U.S. } \\
\text { (1973 Data) } \\
\end{array}$ \\
\hline Coal & 12.38 & & 16.24 \\
\hline Oil & 3.63 & & 1.63 \\
\hline Natural Gas & - & & 4.30 \\
\hline Purchased Electricity & 1.76 & & 1.05 \\
\hline From Utilities & & 1.28 & \\
\hline From Kodo Karyoku Plants & & $.48 *$ & 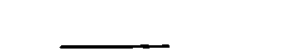 \\
\hline Total Energy (3.0xBtu(elec.)) & $\cdot 21.29$ & & 25.32 \\
\hline Self Generated Electricity & .19 & $-\cdots$ & $\begin{array}{c}----- \\
.26\end{array}$ \\
\hline Coke Oven Gas & 1.69 & & 3.70 \\
\hline Blast Furnace Gas & $\mathrm{N} / \mathrm{A}$ & & 4.42 \\
\hline
\end{tabular}

*A fraction of the fuel input to these plants is blast furnace gas and coke oven gas. 


\section{Aluminium Industry}

The aluminium-making process can be roughly described in three steps; bauxite to alumina (alumina refining), alumina to aluminium (by electrolytic refining) and finally, treatment to finished product (rolling, drawing, etc.). The most important energy input is the electrolytic process, although electricity is also used in the other steps. The anodes in the electrolysis are made of carbon, and a mix of coal products is used for this purpose. Fuels strictly for process heat are mostly natural gas in the United States and heavy oil in Japan, but otherwise the processes used in the two countries are similar. Data presented here is for average energy used per ton of primary aluminum produced; also included is information on the energy use for Japan's "best practice" for 1975. Data for the United States is for 1972 from Rosen ${ }^{14}$ and tor Japan is for 1975 from Mitsubshi Laboratories. ${ }^{17}$ Electricity is converted to primary energy at $3.0 \mathrm{Btu}$ (e) for the United States and for Japan at 2450 kcal/kwhr or primary energy conversion using a factor of 2.85 as utilized by Japanese sources.

Specific energy use in million Btu per ton of aluminum is presented in Table 17. It shows the electricity input to the electrolytic reduction of alumina and consumption of carbon for electrodes at essentially equal levels. The United States figure of 159 million Btu primary equivalent corresponds to $7.76 \mathrm{kwhr} / \mathrm{lb}$. and the Japanese data yields $7.34 \mathrm{kwhrs} / 1 \mathrm{~b}$.

Alumina refining appears $24 \%$ less energy intensive in Japan ( $19 \%$ of the energy is electricity while in the United States it is 13\%). The conversion of aluminium to finished product appears twice as energy intensive in the United States, even though the share of electricity for this process is $68 \%$ in Japan and only $38 \%$ for the United States. The Japanese data however makes no refer- 
TABLE 17

ENERGY USE PER TON OF ALUMINIUM

(MILLION BTU PRIMARY EQUIVALENT)

\begin{tabular}{|c|c|c|}
\hline & Japan & U.S. \\
\hline Alumina Refining & 25.6 & 35.0 \\
\hline Electrolytic Reduction & 142.7 & 159.0 \\
\hline Casting, rolling, drawing, etc. & 15.0 & 33.4 \\
\hline Coal Products for Electrodes & 26.5 & 28.3 \\
\hline & 209.8 & 255.7 \\
\hline
\end{tabular}

ence to aluminium casting, which might indicate that the difference may be due to data inconsistencies.

The Japanese source 17 list the "best practice" for 1975 together with the average for that year. A comparison between the two set of input yields a decrease of $8 \%$ in electricity to electrolysis, one of $58 \%$ in other uses of electricity and an impressive reduction of $76 \%$ in coal input to electrodes. Oil inputs decrease by $10 \%$.

Japan produces domestically $78 \%$ of its aluminium consumption, the rest is imported. The United States produces all its requirements domestically. Cement Industry

It is well known that the cement industry in the United States requires on the average considerably more energy than in other countries, due to the age of the existing capacity. The difference in energy use per ton of clinker between the old wet process ( $56 \%$ of United States capacity) and the newer dry process with suspension preheater ( $12 \%$ of capacity) is 2.15 million Btu per ton, or nearly a factor of two difference. The capital stock turns over very 
slowly because the cement business has had overcapacity for many years and the available investment funds go to pollution control equipment. In contrast, in Japan only $17 \%$ of capacity is by the wet process, and the suspension preheater dry method has $54 \%$ of total capacity and had 73\% of total production in 1975 . It is not surprising then to find that the Japanese average is 4.64 million Btu per ton versus 7.45 million Btu for the United States or $62 \%$ of the energy. The breakdown by fuel is presented in Table 18 from data in $^{17}$ for Japan and ${ }^{14}$ for the United States. Electricity is expressed as primary equivalent as indicated earlier in this report, at a factor of 3.0 for the United States and 2.85 for Japan.

The data in Table 18 shows that in Japan nearly one third of the electricity used by the industry is self-generated and part of it is co-generated. Although not indicated on the table, the Survey of Manufactures ${ }^{5}$ shows selfgenerated electricity by the hydraulic cement industry at $6 \%$ of the amount purchased.

TABLE 18

ENERGY REQUTREMENT PER TON OF CEMENT

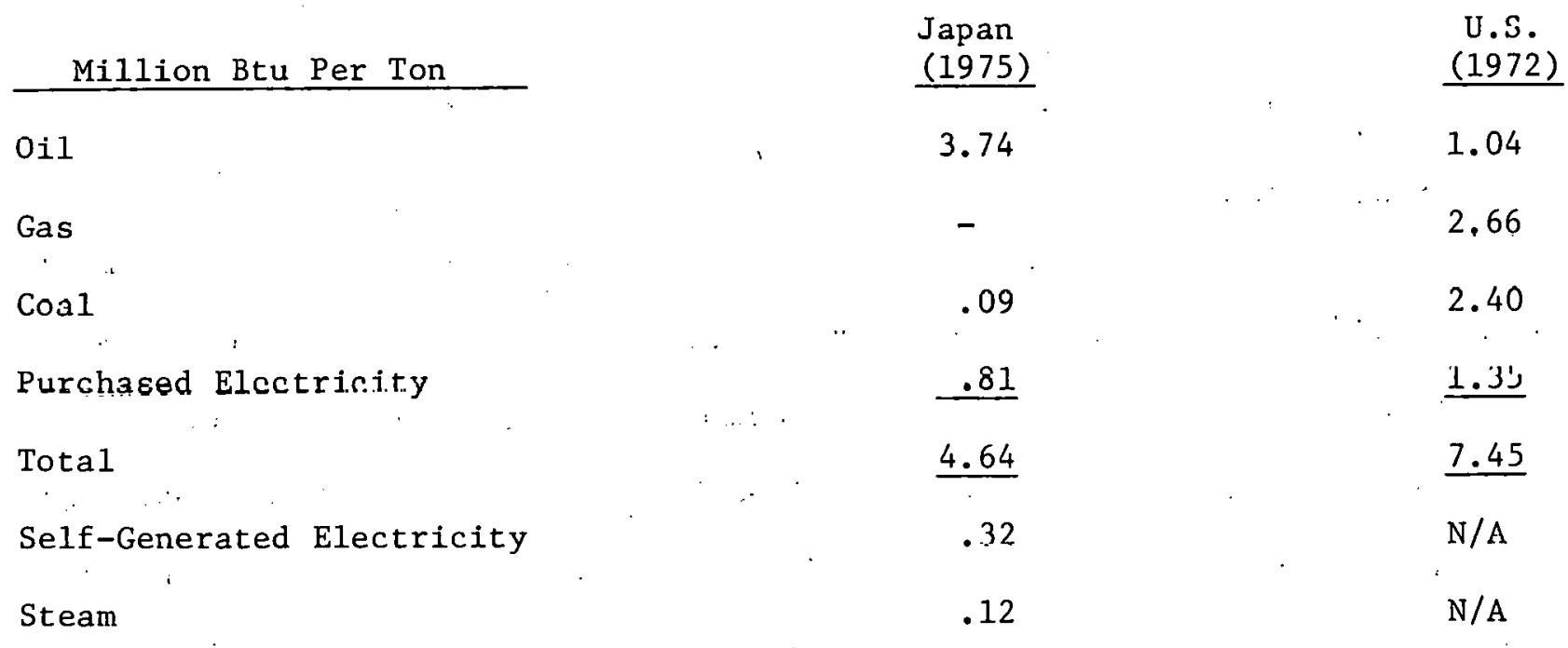




\section{$\underline{\text { Pulp and Paper }}$}

The pulp and paper industry, is a relatively more important industry in the United States than in Japan an therefore is higher in the list of major energy users. Per capita production of pulp is 2.2 times larger in the United States and that of paper 1.7 times larger. The fact that energy consumption per ton of paper (purchased energy only) turns out to be very similar in both countries is probably linked to the relative importance of papermaking in one country versus the other. Japan as a general rule is more efficient than the United States in the industries that are important within its mix, but in less basic industries the specific energy is no better than United States use.

Most statistics within the pulp and paper industries are very similar among the two countries. In the United States $75 \%$ of the pulp is made by the the chemical process and $25 \%$ by the mechanical process; in Japan these ratios are $72 \%$ and $28 \%$ respectively. The different paper products are manufactured in roughly the same proportions: paperboard is $48 \%$ of the total in the United States and $43 \%$ in Japan, printing and writing paper are $28 \%$ and $27 \%$ respectively, packing paper $6 \%$ and $7 \%$, and the only large difference is in newsprint, which is $6 \%$ of the total in the United States and $12 \%$ in Japan.

Energy use per ton of paper is presented in Table 19 from data in ${ }^{17}$ and from $^{14}$. It shows a total of 23.8 million Btu per ton for Japan and 25.5 million Btu for the United States. These figures only include purchased energy. Wood by-products (liquors, bark) used as fuels would add around $60 \%$ to the United States use per ton, and it is probably no different in Japan. Also left out of 'lable 19 is self-generatcd electricity, which for this industry is relatively high even in the United States. 


\section{PURCHASED ENERGY PER TON OF PAPER}

$10^{6}$ Btu per ton of paper

Oil

Coal

Natura1 Gas

Electricity (primary eg.)

Purchased Steam
Japan

$\underline{(1975)}$

18.2

.1

$-$

5.5

$\underline{N} / \mathrm{A}$

23.8
U.S. $\underline{(1972)}$

8.0

4.2

7.6

5.4

.3

25.5

Specific energy demands per ton of paper published by Japanese sourres show fluctuations through the years but no clear trend downwards. The average consumption for the last ten years is slightly lower than the 1975 figure, 22.8 million Btu, and has been as low as 21.6 million Btu per ton of paper.

\section{III-3 TRANSPORTATION SECTOR}

The transportation sector shows dramatic differences between the United States and Japan, both in the choice of mode and in the intensity of use. More passengers are carried in Japan by railroad than by automob1le, especially for longer trips. Railroads carried $40 \%$ of the passengers but accounted for $48 \%$ of the passenger kilometers, while auto carried $34 \%$ of the pannengers and accuunted for on $1 \mathrm{y} 31 \%$ of the passenger $\mathrm{kms}$. For the United States, auto travel accounts

for $91 \%$ of the total passenger kms with air travel accounting for most of the remainder. This briefly indicates that essentially we are observing two totally 
different transportation systems. There are over 9 persons in Japan per automobile, while in the United States there are not quite 2 persons per auto. The existence of a high speed ultra modern railroad system in Japan makes the choice between modes quite different to that of the United States traveler faced with a deficient railroad system and superb highways. The question of satisfaction is nevertheless still open.

The consumption of fossil energy yields 79.9 million Btus per capita for the United States and 15.6 million Btu for Japan or 19.5 percent. Table 20 shows the energy per capita for both countries by travel mode. The largest part of this difference is travel intensity or the amount of transportation services demanded (measured as passenger miles and ton miles of freight). This makes the two systems impractical to compare. Passenger travel is only $33 \%$ of that of the United States, and freight haulage only $26 \%$. Clearly a large contribution to this difference originates in the distribution of the population. The simplest measure of it is density, which shows 733 persons per square mile in Japan versus 57 in the United States. This wide disparity suggests that it is not worthwhile to produce indicators beyond this very crude measure of distribution to underscore the vast differences on demand for transportation serviress due to population distribution.

Table 21 shows travel patterns by mode. Passenger traffic shows a predominace of rail in Japan, and the automobile in the United States. In freight transportation, truck and ship can be explained by population distribution and the relatively lower economic activity in Japan (i.e., GUP per cap1ta) while the substantially higher use of railroad freight in the United States is probably linked to the large extractive industries absent in Japan. It is important to note that overseas freight (not included here) is an important component in 
TABLE 20

TRANSPORTATION ENERGY, 1974

$10^{6 \mathrm{Japan}} \mathrm{Btu} / \mathrm{cap}$
.30
.35
6.6
.5
5.1
.6
2.5
15.6

$10^{6^{\mathrm{U}} \text { Bt. S. }}$ Btcap

2.70

.09

43.6

.5

21.6

7.7

3.8

79.9

\section{Percent}

11 .

389.

15.

100.

24.

8.

66.

20.

Source: Reference 8. 
TABLE 21

TRANSPORTATION INTENSITIES, 1974

\begin{tabular}{|c|c|c|c|}
\hline \multirow{2}{*}{\multicolumn{4}{|c|}{ Passenger (per capita pass mi) }} \\
\hline & & & \\
\hline Railroad & 1,830 & 49 & 3,700 \\
\hline Air, domestic & 99 & 693 & 14 \\
\hline Bus & 654 & 296 & 220 \\
\hline Automobile & 1,201 & 10,476 & 11 \\
\hline Total & 3,784 & 11,514 & 33 \\
\hline \multicolumn{4}{|c|}{ Freight (per capita sh ton mi) } \\
\hline Railroad & 327 & 4,069 & 8 \\
\hline Truck & 818 & 2,342 & 35 \\
\hline Ship & 1,198 & 2,774 & 43 \\
\hline Total & 2,379 & 9,185 & 26 \\
\hline Vehicles miles per auto & 7,709 & 9,265 & 83 \\
\hline Auto efficiency (mpg) & 19.0 & 13.8 & \\
\hline
\end{tabular}


Japan's transportation intensity due to imports of raw materials (fuels, ores, lumber) and exports of finished goods.

The pattern of automobile ownership is different among the two countries. According to the available statistics, automobile usage in high in Japan, 7709 miles per vehicle per year, or $83 \%$ of that of the United States. This similarity in average travel is due to the existence of a sizable number of second cars in the United States that have very low yearly use (35\% of total households have 2 or more autos), tending to depress the average. Japan consists of primarily one-car families, and their American counterparts travel relatively many more miles than the statistics tend to show. Average efficiency for the fleet of Japan's automobiles is $19.0 \mathrm{mpg}$ (official sources cite $598 \mathrm{Kcal} / \mathrm{pass}$ $\mathrm{km}$, at a load factor of 1.48 obtained from passenger-km and vehicle-km data). 'l'he average for the. United States, obtained from fuels consumption and vehicle mile data, yields $13.8 \mathrm{mpg}$ for 1974. The use of automobile for business related travel is similar, at $7 \%$ of total auto passenger miles travelled for Japan and $6 \%$ of the total in the United States.

Wther efficiencico are preseilled in Table 22. 'lhe Japanese data is obtained from official estimates for 1974 and the United States data is from Faucett ${ }^{15}$ for 1972. As presented here (in Btu per pass mile or Btu per ton mile) not much can be said about relative technological efficiencies because of a number of reasons, the most important being average load factors assumed in the calculations and a description of the types of vehicles or craft in the respective fleets. 


$\begin{array}{lrr} & \text { Japan } & \text { U.S. }{ }^{2} \\ \text { Auto (mpg) } & 19.0 & 13.8 \\ \text { Air (Btu/pass mi) } & 6,088 . & 7,899 . \\ \text { Bus (Btu/pass mi) } & 786 . & 1,432 . \\ \text { Truck (Btu/ton mile) } & 5,026 . & 384 . \\ \text { Rail (Btu/ton mile) } & 856 . & 567 . \\ \text { Ship (Btu/ton mile) } & 1,118 . & \\ & & \end{array}$

III-4 RESIDENTIAL SECTOR

The residential sector typifies the difference between Japanese consumption patterns and those of the United States. Energy use in households is lower than their United States counterparts and the fuel forms are different. The barrier to a meaningful comparison is the degree to which this analysis can separate efficiency of end use devices from the satisfaction (or convenience) the United States homeowner receives from having larger homes, bigger appliances, and central heating systems. There is fortunately adequate data available to point out these differences in detail.

On a per capita basis, Japanese per household consumptlun is less than $19 \%$ of that of th.e United States (Table 23), with space heating, the largest single use in the United States, being the largest contributor to this differ- 
TABLE $\cdot 23$

FUELS TO RESIDENTIAL SECTOR, 1974

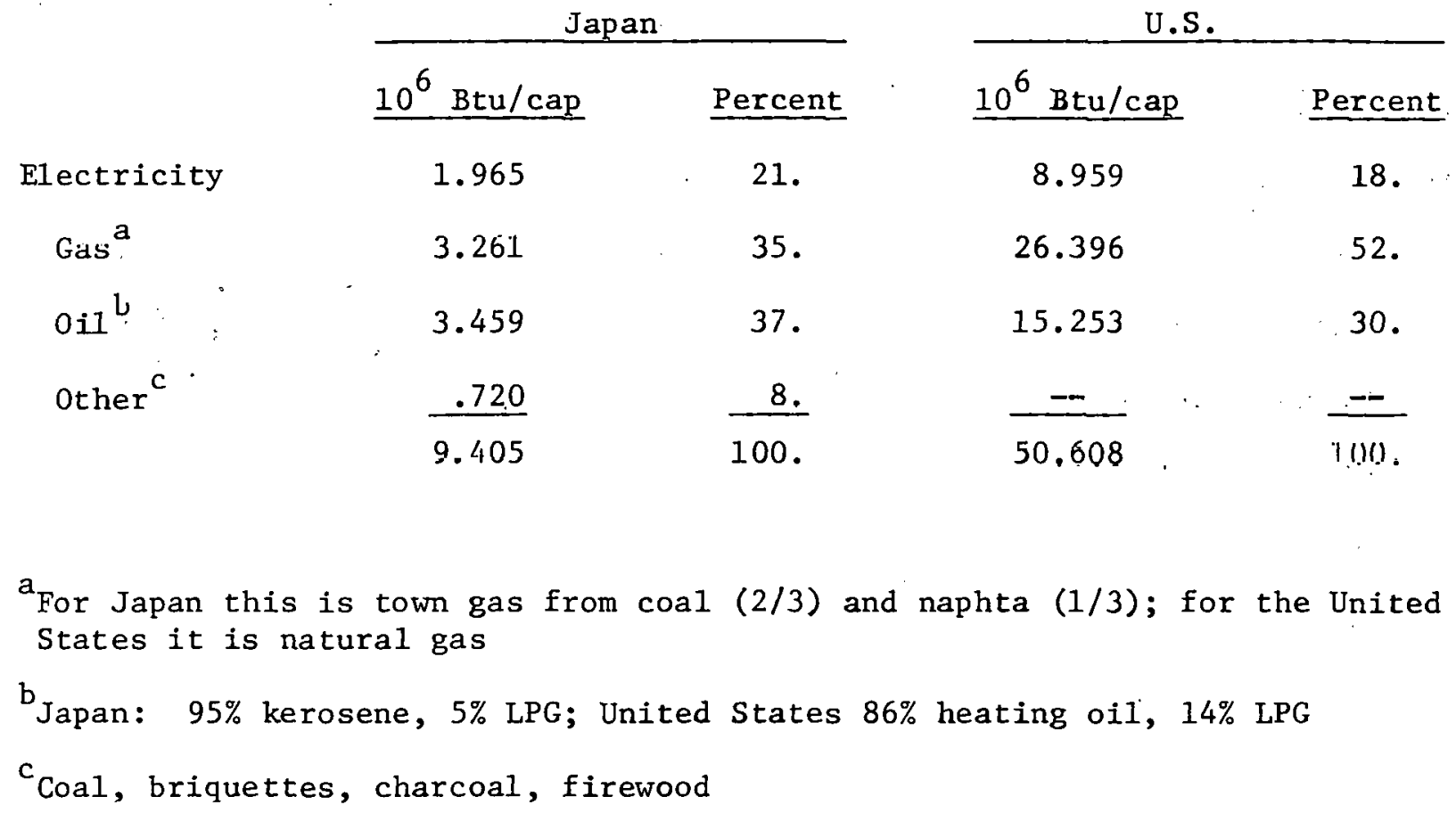

ence at about $12 \%$ of United States use (Tah1e 24). The two main factors besides usage patterns are climate and size of hnising. The rough population woighted average temperature for Japan is approximately $15.0^{\circ} \mathrm{C}$ or $59^{\circ} \mathrm{F}$, but there is a range nearly as large as that of the United States. The main Iapanoso iolando are at latitudes that correspond to the area between Maine and Northern Florida. The northwestern region of the archipelago reportedly has the largest accumulation of snowfall of any comparahle densely inhabited location in the world, wh1lc the southern islands are mild year-round.

Housing size is significantly smaller in Japan, $830 \mathrm{sq}$. ft. floor area per dwelling $\left(77.14 \mathrm{~m}^{2}\right)$ versus $1,300 \mathrm{sq}$. ft. here (the United States figure re- 
TABLE 24

RESIDENTIAL PRIMARY ENERGY CONSUMPTION ${ }^{1}$

$\begin{array}{ll}\text { Japan } & \text { U.S. } \\ \begin{array}{l}10^{6} \text { Btu/ } \\ \text { household }\end{array} & \begin{array}{l}10^{6} \text { Btu/ } \\ \text { household }\end{array}\end{array}$

Space Heating

Water Heating

Cooking

Refrigeration

Lighting
14.4

9.5

6.4

4.7

3.5
113.6

30.1

10.6

11.8

11.7
Fraction

.13

.32

.60

.40

.30

${ }^{1}$ Electricity at 3 times end use input

Sources: Japan: Reference 8

U.S.: Reference 12

fers to new construction). Single family homes in Japan comprise $65 \%$ of the total, and over $90 \%$ of the multifamily units are low-rise (under 5 stories). The fuel types are also different. Petroleum is used as kerosene (mainiy for spare heat), which is a lighter product than the heating oil that predominates in United States homes heated by oil. Its distribution system is radically different; kerosene is mainly bought in small quantities at gasoline service stations (5-10 gallons at a time) while heating oil is distributed by truck into 100-200 gallon tanks. The town gas used in Japan (going mostiy to cooking with a small fraction used for space heat) is the gas traditionally manufactured from coal but presently one third is made from petroleum (naphtha). It was also the gas used in the United States before World War II and elsewhere 
at the time no natural gas distribution system existed. Its heating value is about one half that of natural gas, or $500 \mathrm{Btu} / \mathrm{cu}$. ft.

Space Heat: Homes are heated in Japan with room heaters and stoves. Very few units are centrally heated, as are $85 \%$ of the homes in the United States. Kerosene heats $78 \%$ of the total, town gas $13 \%$ and electricity $9 \%{ }^{8}$ This distribution was obtained from the breakdown of the stock of appliances, i.e., it assumes the number of room heaters per household is evenly distributed among fuels. One unique feature in Japan's home heating is the "kotatsu," a small heating unit (usually electric) that is present in practlcally all homes. It is attached under a table covercd with a lieavy tablecloth. People sit around the table and tuck their legs under the tablecloth. This energy thrifty setup is an unlikely candidate for technology transfer, and is a vivid example of culture determining energy consumption levels quite independently from the concept of conversion efficiency.

Air Conditioning: There is nearly one room air conditioner per every four households in Japan. These consume $8.8 \%$ of the total electricity to the residential sector. These units are estimated to consume $719 \mathrm{kwhr} / \mathrm{year}$; the estimate for the United States is nearly double, or $1378 \mathrm{kwhr}$ per room $\mathrm{A} / \mathrm{C}^{12}$. Penetration rates are much higher in the United States, where in $197433 \%$ of all households had at least one room air conditioner and $20.6 \%$ had central ni.r. conditioning.

Water Heating: Fewer than $1 \%$ of water heaters are electric in Japan, gas beilig llie must popular, and coal, briquettes and so on still being used by $14 \%$ of the households. Although omitted in official statistics, over 1 million solar water heaters have been installed in Japan. In per household terms, Japan uses less than one third of the energy used by United States 
homes (Table 24), most likèly due to smaller units. It must also be added that communal baths are part of family tradition in Japan.

Cooking: The most common appliance for cooking in Japan is the gas table ( $90 \%$ saturation), while ovens are present in less than one third of the households (gas $17 \%$ and microwave ranges $11 \%$ ). The predominant fuel is gas, and when accessory items such as rice cookers (50\% electric, $50 \%$ gas) are added to cooking needs, the use is $60 \%$ of the United States level per household (Table 24). Not only is the hardware in the kitchen somewhat different to the average American set, but foods and food preparation are vastly different among the two cultures. These appear to yield the energy "savings" indicated above.

Refrigeration: Ownership of refrigerators is at $100 \%$ saturation in Japan, but the units are smaller than those in the United States. Japanese data indicates 453 kwhrs average electric use per year for refrigerators, while in the United States a range is given from $728 \mathrm{kwhr}$ to $1829 \mathrm{kwhr}$ for 12 cubic ft. units and $14 \mathrm{cu}$. ft. frostless units respectively. Even the latter are not the $1 \mathrm{arg}-$ est ones available and this difference in the size of the stock accounts for Japan's average use being 2.5 times smaller (Table 24). In addition, one third of United States households have separate food freezers which are not used in Japan.

Lighting: Japanese sources cite yearly consumption per household at 296,000 Kcal or $313 \mathrm{kwhrs.} \mathrm{Average} \mathrm{for} \mathrm{the} \mathrm{United} \mathrm{States} \mathrm{is} \mathrm{estimated} \mathrm{at} 1130$ kwhrs per year by Dole, ${ }^{12}$ or 3.3 times greater.

Other Appliances: Table 25 contains a list of the most important appliances, and it can be seen that Japan's households are very well stocked with them but average yearly consumption appears much smaller. This can be due to 
TABLE 25

ENERGY USE AND OWNERSHIP OF APPLIANCES

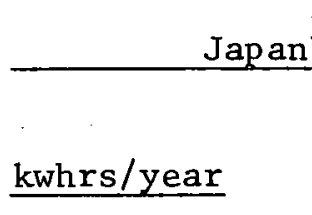

$n^{1}$

U.S. ${ }^{2}$

Percent

719

Ownership

Air Conditioning

24.

453

100.

Refrigerator

234

95.

U.S.
kwhrs/year

Percent

Color T.V.

27

64.

$1370^{\mathrm{a}}$

Ownership

B/W T.V.

40

98.

$728-1829^{b}$

54

Washing Machine
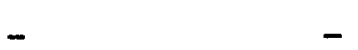

993

48

Dishwasher

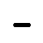

$-$

363

22

Food Freezer

$\dot{-}$

$-$

-

32

Iron

40

92.

144

$a_{\text {Data }}$ for a room air conditioning unit

${ }^{b} 12 \mathrm{cu}$. $\mathrm{Cl}$. regular to $14 \mathrm{cu}$. ft. frostless

${ }^{1}$ Data for Japan is from $^{8}$

2 Data collected principally from ${ }^{12}$ and $^{19}$ 
a combination of factors: intensity of use (hours of T.V. viewing per day), size of appliances and technological factors (instant on T.V. sets).

\section{III-5 COMMERCIAL SECTOR}

Per capita energy use in this sector appears to be at approximately the same ratio as in the residential sector (20\% of United States levels) for Japan. The commercial sector is not well covered by United States data, sources, and it becomes especially difficult to match subsectors (offices, stores, etc.) between the two countries with the available data. Table 26 shows data for Japan for 1972 broken down by commercial building types and end use. Also included is total square footage (or square meters) and energy per square foot. The data for Japan is very adequately tabulated by building types that are similar energy users. Unfortunately, the most comprehensive data base for United States energy use in this sector, developed by Faucett Assoc., Inc. ${ }^{16}$ is organized by economic activity (wholesale trade, public administration, services etc.) and not by building type. This data is presented in Table 27. Thus, office space is part of all categories except schools and hospitals, while retail trade includes such dissimilar users as stores and restaurants, and hotels and garages end up under finance, real estate and services. Also lacking in the report is total square footage for the commercial sector. This figure is reported as 21.61 billion square feet for 1970 by A. D. Little (Project Independence and Energy Conservation: Volume 1) and by extrapolating to 1972 we obtain 114 square feet per capita. The dala furr Japan prcoented here yields for the same year 106 square feet per capita (after deducting factnry space which is not included in the United States total). These figures naturally are only roughly comparable because of the degree of uncertainty in the data compilation. 
ENERGY USE, COMMERCIAL SECTOR, JAPAN $1972^{1}$

\begin{tabular}{|c|c|c|c|}
\hline & $\begin{array}{c}\text { Percent } \\
\text { of Tota1 } \\
\text { Area }\end{array}$ & $\begin{array}{l}\text { Percent of } \\
\text { Energy Use }\end{array}$ & Btu/Sq. Ft. \\
\hline Offices (incl. govn't) & 9.6 & 15.5 & 59700 \\
\hline Retail Stores & 9.1 & 22.4 & 90600 \\
\hline Restaurants & .5 & 1.3 & 87000 \\
\hline Amusements & 1.1 & 3.5 & 113800 \\
\hline Hotels, lodgings & 7.6 & .45 .5 & 220000 \\
\hline Wholesale, warehouse & 36.8 & 1.8 & 1840 \\
\hline Faclurtes & 26.2 & $2 . \dot{9}$ & 4000 \\
\hline Public Lighting & 2.8 & - & 1840 \\
\hline Schools, Hospitals & 6.1 & .7 .1 & 5500 \\
\hline $\begin{array}{l}\text { Gas, Water Sewage Utils. } \\
\text { Total }\end{array}$ & $\begin{array}{c}0.2 \\
1,428,843 \mathrm{~m}^{2}\end{array}$ & $142,9.18 \times 10^{9} \mathrm{Kca} 1$ & $\begin{array}{r}4000 \\
36800\end{array}$ \\
\hline
\end{tabular}

Energy Use Breakdown

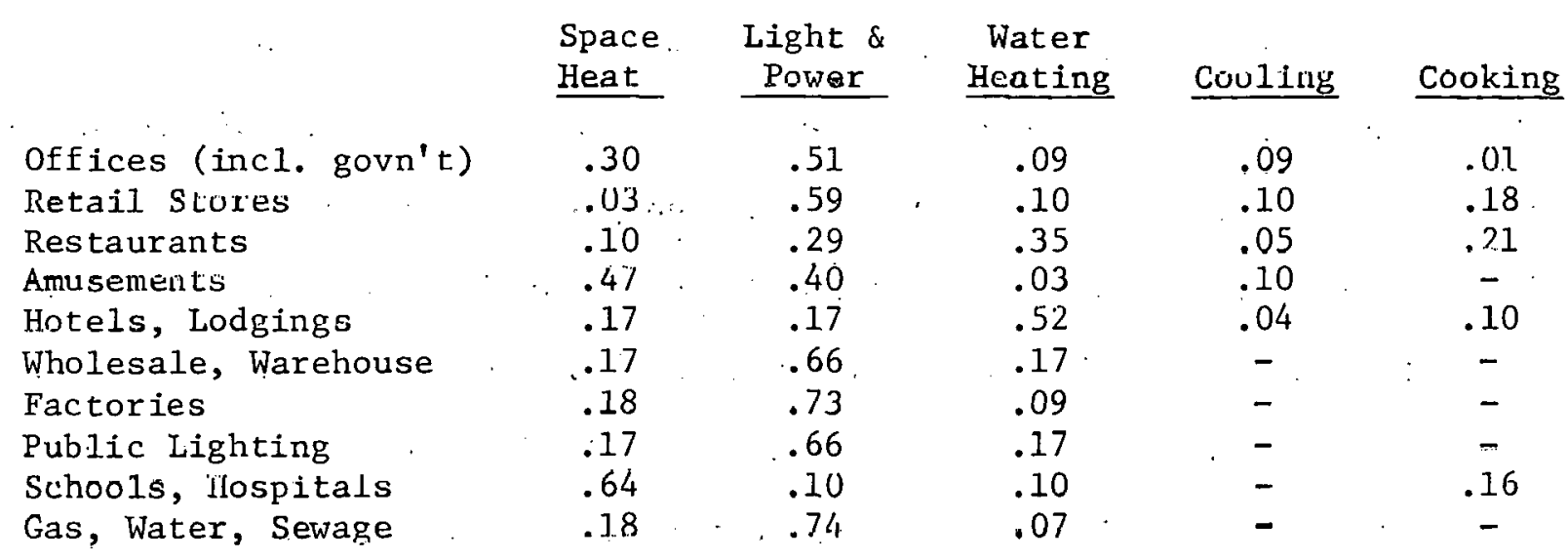

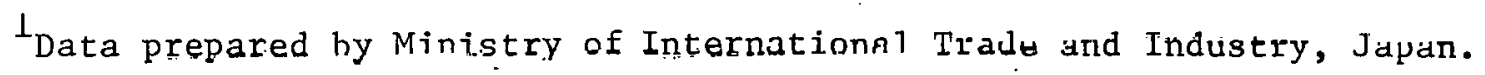


TABLE 27

U.S. COMMERCIAL ENERGY USE, $1974\left(10^{12} \mathrm{Btu}\right)$

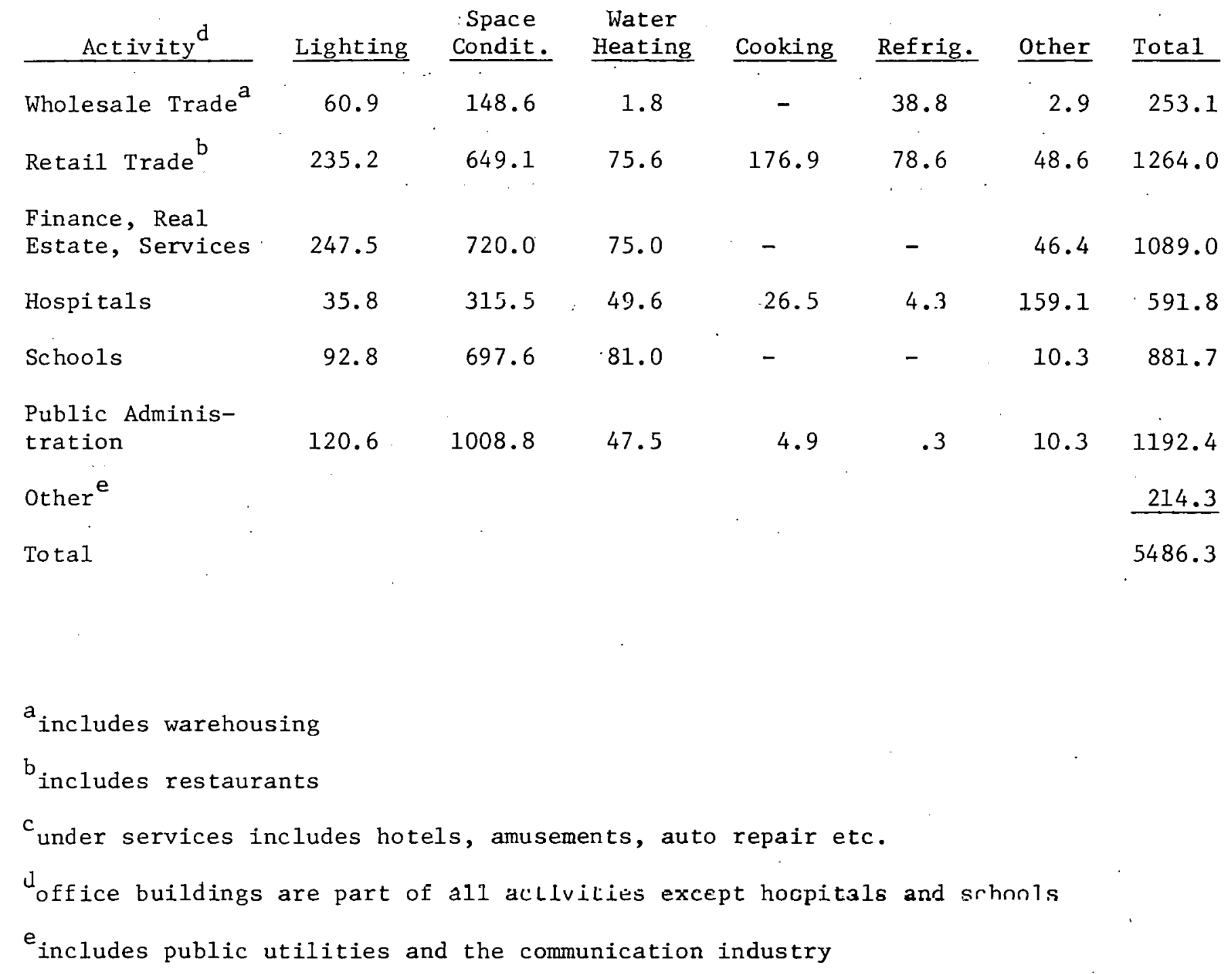

Source: Jack Faucett Assoc., Inc. ${ }^{16}$ 
Of all subsectors presented in Tables 26 and 27 only hospitals and schools lack ambiguities in definition and can be compared. This yields overall energy consumption (per capita) for Japan of only 5\% of the United States. This is much lower than the $20 \%$ figure for the commercial sector as a whole. But further analysis into the makeup of these data reveals a problem in performing a meaningful comparison. For the United States, nearly one half of the number of beds that are the basis for the calculation of energy consumption for hospitals belong to nursing homes, institutions which are essentially. non-existent in Japan. For schools, energy use in the United States is magnified by the inclusion of campus dormilurles, Which are very uncommon in Japan. It can be seen that even if consistent data were available on square footage per capita for hospitals or schools, an apparent gain of one country over another is not a measure of "standard of living" because other aspects of culture (such as elders living in institutions versus staying with families) are not equal. While a case can be made for cultural similarities among countries, for instance, in northern Europe, it is very far from being the case for .Tapan and the United States.

The data presented in Table 26 for Japan covers about 43\% of the energy used in the Commercial sector as described from the supply side (Table 3). The makeup of this difference is unclear, but prohably iublude uocs not classilied elsewhere such as agriculture and fisheries, and the inclusion of some rental multi-family buildings under the commercial sector. The latter are very commonly classified as commercial by the utilities supplying the fuels. 


\section{REFERENCES}

1. A Doernberg, "Comparative Analysis of Energy Use in Sweden and the United States," BNL-20539 (September 1975), Brookhaven National Laboratory, Energy Technology Assessment Group, Upton, N.Y.

2. C. Cook, et al.; "Japanese Energy R + D: The Policy Context," WN-9427ERDA, (March 1976), Rand Corp., Santa Monica, Calif.

3. "With Heavy Import, Disciplined People Keep Oil Demand Low," International Herald Tribune, (January 17, 1977).

4. Bureau of Statistics, Office of the Prime Minister, Japan Statistical Yearbook 1975, (April 1975).

5. United States Department of Commerce, Bureau of the Census, "Annual Survey of Manufactures, 1974: Fuels and Electr1c Energy Consumed," M74-(AS)4.2, (September 1976).

6. American Iron and Steel Institute, "Annual Statistical Report, 1974," (May 1975).

7. United States Department of Interior, Bureau of Mines, Newsrelease, "Annual United States Energy Drops Again," (April 5, 1975).

8. Data Appendix of Japan for "An Initial Multi-National Study of Future Energy Systems and Impacts of Some Evolving Technologies," BNL-50641, Ju1-1406, March 1977, prepared by Brookhaven National Laboratory and Kernforchungsanlage Julich. Also, Data Appendix of the United States.

9. Organization for Economic Cooperation and Development, Department of Economics and Statistics, "National Accounts of OECD Countries, 1974."

10. I. B. Kravis, et al., A System of International Comparison of Gross Product and Purchasing Power, (John Hopkins University Press, 1975), United Nations International Comparison Project, Phase One.

11. United Nations, Statistical Yearbook 1974, (N.Y., 1975).

12. S. H. Dole, "Energy Use and Conservation in the Residential Sector: A Regional Analysis," R-1641-NSF, (June, 1975), Rand Corp., Santa Monica, Calif.

13. Unpublished notes prepared by participants of the International Energy Agency Systems Analysis Project, at Brookhaven National Laboratory, (1976).

14. R. Rosen, work in progress at Brookhaven Nat1onal Laboratory for ERDA AA for Conservation.

15. J. Faucett Assoc. Inc., "Project Independence and Energy Conservation: Transportation Sector," Volume 2, (November, 1974). 
16. J. Faucett Assoc. Inc., "Energy Consumption in Commercial Industrials. by Census Division - 1974," (December 1976).

17. Mitsubishi Laboratories, "Quantitative Analysis of the Efficiency of Energy Consumption Within the Industrial Sector," NRC-75-1a, (September 1976).

18. Ministry of Transportation, Transportation Economic Abstract (Tokyo, 1976).

19. United States Department of Commerce, Bureau of the Census, Statistical Abstract of the United States: 1975 (96th edition) (Washington, D.C. 1975).

20. J. C. DeHaven, "Energy Prices In. Japan: A Preliminary Assessment," WN-9426-ERDA (March 1976), Rand Corp., Santa Monica, Calif..

21. Federal Power Commission, "Typical Electrte Bills,". (December 1974). 